\title{
Assessment of methods used for 3-dimensional superimposition of craniofacial skeletal structures: $A$ systematic review
}

\author{
Daniel Dinh-Phuc Mai ${ }^{1}$, Sven Stucki ${ }^{1}$, Nikolaos Gkantidis ${ }^{\text {Corresp. } 1}$ \\ ${ }^{1}$ Department of Orthodontics and Dentofacial Orthopedics, University of Bern, Bern, Switzerland \\ Corresponding Author: Nikolaos Gkantidis \\ Email address: nikosgant@yahoo.gr
}

Background. So far, several techniques have been recommended for the assessment of craniofacial changes through skeletal tissue superimposition, but the evidence that supports them remains unexplored. The purpose of the present study is to assess the available literature on skeletal-tissue superimpositions of serial craniofacial CT or CBCT images used to detect morphological changes. Materials and methods. Medline (via Pubmed), EMBASE, Google Scholar, Cochrane Library, Open Grey and Grey Literature Report were searched (last search: 17.11.2019) using specific terms that fulfilled the requirements of each database in the context of the study aim. Hand searches were also performed. The outcomes of interest were the accuracy, precision, or agreement between skeletal-tissue superimposition techniques to assess changes in the morphology of craniofacial structures. Studies of any design with sample size $\geq 3$ were assessed by two authors independently. The study protocol was registered in PROSPERO (ID:

CRD42019143356). Results. Out of 832 studies, fifteen met the eligibility criteria. From the 15 included studies, 12 have shown high total risk of bias, one low risk of bias, and 2 studies have shown unclear risk of bias. Thirteen out of the 15 studies showed high applicability concerns, 2 unclear and no study had low applicability concerns. There was high heterogeneity among studies regarding the type of participants, sample size, growth status, machines, acquisition parameters, superimposition techniques, assessment techniques and outcomes measured. Fourteen of them were performed on Cone Beam Computed Tomography (CBCT) and one on Computed Tomography (CT) derived 3D models. Most of the studies (eleven) used voxel-based registration, one landmark-based registration and three studies compared different registration techniques, which include the surface-based registration. Concerning the area of interest, nine studies focused on the anterior cranial base and certain facial structures, four on maxillary structures and four on mandibular structures. Non-growing participants were included in six studies, growing in eight, whereas one study had hoth. Conclusion. Most of the available studies had
Peer] reviewing PDF | (2020:03:46530:1:2:NEW 6 May 2020) 
methodological shortcomings and high applicability concerns. At the moment, certain voxel-based and surface-based superimpositions seem to work properly and to be superior to landmark-based superimposition. However, further research in the field is required to develop and properly validate these techniques on different samples, through high quality studies with low applicability concerns. 


\section{Assessment of methods used for 3-dimensional superimposition of craniofacial}

2 skeletal structures: a systematic review

3 Daniel Dinh-Phuc Mai ${ }^{1}$, Sven Stucki ${ }^{1}$, Nikolaos Gkantidis ${ }^{1}$

4

$5{ }^{1}$ Department of Orthodontics and Dentofacial Orthopedics, University of Bern, Freiburgstrasse 7, 6 CH-3010, Bern

7

8 Corresponding Author

9 Nikolaos Gkantidis, Department of Orthodontics and Dentofacial Orthopedics, University of

10 Bern, CH-3010, Freiburgstrasse 7, Bern, Switzerland

11 Tel.: +41 (0) 3163225 92, Fax: +41 (0) 316329869

12 Email: nikolaos.gkantidis@zmk.unibe.ch; nikosgant@yahoo.gr 


\section{AbSTRACT}

15 Background. So far, several techniques have been recommended for the assessment of

16 craniofacial changes through skeletal tissue superimposition, but the evidence that supports them

17 remains unexplored. The purpose of the present study is to assess the available literature on

18

19

20

21

22

23

24

25

26

27

28

29

30

31

32

33

34

35

36

37

38

39

40

41

42

43 skeletal-tissue superimpositions of serial craniofacial CT or CBCT images used to detect morphological changes.

Materials and methods. Medline (via Pubmed), EMBASE, Google Scholar, Cochrane Library, Open Grey and Grey Literature Report were searched (last search: 17.11.2019) using specific terms that fulfilled the requirements of each database in the context of the study aim. Hand searches were also performed. The outcomes of interest were the accuracy, precision, or agreement between skeletal-tissue superimposition techniques to assess changes in the morphology of craniofacial structures. Studies of any design with sample size $\geq 3$ were assessed by two authors independently. The study protocol was registered in PROSPERO (ID: CRD42019143356).

Results. Out of 832 studies, fifteen met the eligibility criteria. From the 15 included studies, 12 have shown high total risk of bias, one low risk of bias, and 2 studies have shown unclear risk of bias. Thirteen out of the 15 studies showed high applicability concerns, 2 unclear and no study had low applicability concerns. There was high heterogeneity among studies regarding the type of participants, sample size, growth status, machines, acquisition parameters, superimposition techniques, assessment techniques and outcomes measured.

Fourteen of them were performed on Cone Beam Computed Tomography (CBCT) and one on Computed Tomography (CT) derived 3D models. Most of the studies (eleven) used voxel-based registration, one landmark-based registration and three studies compared different registration techniques, which include the surface-based registration. Concerning the area of interest, nine studies focused on the anterior cranial base and certain facial structures, four on maxillary structures and four on mandibular structures. Non-growing participants were included in six studies, growing in eight, whereas one study had both.

Conclusion. Most of the available studies had methodological shortcomings and high applicability concerns. At the moment, certain voxel-based and surface-based superimpositions seem to work properly and to be superior to landmark-based superimposition. However, further

Peer] reviewing PDF | (2020:03:46530:1:2:NEW 6 May 2020) 
44 research in the field is required to develop and properly validate these techniques on different 45 samples, through high quality studies with low applicability concerns. 


\section{INTRODUCTION}

47 Superimpositions of serial craniofacial images have been widely applied in dental or other fields

48

49

50

51

52

53

54

55

56

57

58

59

60

61

62

63

64

65

66

67

68

69

70

71

72

73

74

75

76

as a mean to depict changes over time. It is a valuable tool facilitating the better understanding of the effects of treatment or growth on dental and craniofacial morphology. The "structural method" developed by Björk (Björk, 1969; Björk \& Skieller, 1977) is still considered today as the standard 2D superimposition technique for craniofacial radiographs. This is based on reference structures that are considered stable, allowing the visual inspection of craniofacial changes relative to these stable structures. Such 2D methods were adopted and modified to be applicable in 3D data, since the same principles for reference area selection apply to both 2D and 3D approaches.

There are several advantages of the 3D over the 2D imaging techniques including the more accurate, real size information in all dimensions of space. Furthermore, the $3 \mathrm{D}$ information is not highly dependent on head positioning, which might be a critical source of error in 2D imaging. However, the higher amount and quality of $3 \mathrm{D}$ information does not come without a cost. This has to do mainly with the increased radiation dose needed to obtain the 3D images. Moreover, the data acquisition, handling, and processing of 3D data is usually more complex, time consuming, and expensive.

In growing individuals, the identification of stable superimposition reference areas might be more difficult, since the morphology of most craniofacial structures changes considerably over time. Thus, changes in the reference areas might affect the superimposition outcomes on the areas of interest, due to the icomplete matching of the first. For this reason, similar to the registration in $2 \mathrm{D}$, the anterior cranial base still holds its position as the gold standard reference area, since its growth is more or less completed around the age of seven (Buschang et al., 1986; Afrand et al., 2014). To include this part of the head in the 3D images requires a larger field of view, and thus, larger dose of radiation. Furthermore, structures that are more vulnerable to radiation exposure, such as the eyes or certain brain structures, are included. Due to this fact, researchers have explored other possibilities, to substitute the anterior cranial base as a superimposition reference, which can be applied in smaller field of view scans and still perform properly (Nada et al., 2011; Gkantidis et al., 2015).

Following the development of such methods and due to the technological advancements, that can lead to $3 \mathrm{D}$ image acquisition with small radiation exposure, in the foreseeable future, large

Peer) reviewing PDF | (2020:03:46530:1:2:NEW 6 May 2020) 
77 amount of reliable 3D data could be generated. This could facilitate the valid prediction of 78 morphological changes that will occur in a specific patient after a certain treatment or growth

79 80 future.

81 Since the first application of 3D superimposition, three main techniques have been used for serial 82 83 84 85 86 87 88 image registration: namely landmark-based, surface-based, and voxel-based techniques (Grauer, Cevidanes \& Proffit, 2009; Cevidanes et al., 2010; Almeida et al., 2011; AlHadidi et al., 2011). Each technique has been widely used for clinical and research purposes and has inherent limitations, advantages, and disadvantages. Furthermore, all techniques have been suggested in the literature to work properly. Various relevant studies have been published so far, but the heterogeneity of the protocols, machines, acquisition parameters, and superimposition references did not allow for the development of solid conclusions (Ponce-Garcia et al., 2018). The only existing systematic evaluation of the literature included studies that were published prior to 2017 and regarded only the anterior cranial base (Ponce-Garcia et al., 2018). Thus, neither the accuracy, the precision, and the reproducibility of hard-tissue superimposition techniques nor the choice of reference structures have been thoroughly investigated recently. Hence, the purpose of this review is to provide a synopsis and a thorough assessment of the current evidence, aiming to provide guidelines for the proper use of the techniques and interpretation of the outcomes and identify areas where further research is needed.

\section{MATERIALS AND MeTHODS}

\section{Protocol and registration}

The protocol was registered in PROSPERO prior to the study implementation (ID: CRD42019143356). This protocol consists a modification of a previously published protocol by Stucki \& Gkantidis (2019) for an analogous, but completely different topic.

\section{Search strategy}

The following databases were searched for eligible studies: Medline (via Pubmed), EMBASE, Google Scholar, Cochrane Library, OpenGrey and GreyLiteratureReport. The last search was performed on 17.11.2019, without time restriction. Unpublished literature was searched through the National Research Register, Pro-Quest Dissertation Abstracts and Thesis database, additional 
107 hand searches of all relevant studies were also performed. The specific search strategies applied

108 for each database are provided as supplementary information (Appendix 1).

\section{Selection criteria applied for the review}

110 - Study design: Any study design, including prospective, and retrospective studies of any type.

111 - Study sample: Studies with sample size $\geq 3$.

112 - Index test: 3D skeletal-tissue superimposition techniques to assess any change in the

113 morphology of the craniofacial complex.

114 - Types of participants: Serial craniofacial CT or CBCT images of individuals or skulls who have 115 received any kind of actual or simulated treatment, or whose craniofacial morphology is

116 expected to be altered due to growth or pathology.

117 - Type of intervention: 3D skeletal-tissue superimposition to assess any morphological change in 118 the craniofacial complex.

119 - Primary outcome: Superimposition accuracy or precision of a technique, or agreement between

120 techniques measured in terms of angles or distances between specific skeletal or facial landmarks

121 or area distances between corresponding models. Volume differences measured following 3D

122 superimposition were also considered. Studies that evaluated any of the above parameters as a

123 secondary outcome were also included.

124 - Comparator/control group: Studies that compared different superimposition techniques, direct

125 measurements, or repeated measurements were selected.

126 - Unit of analysis: The measured distance, angle, or volume.

127 - Follow-up: Any observation period between subsequent models.

128 - Exclusion criteria: None.

\section{Study selection}

130 Following the search strategy, the selected databases were screened by two authors of the review 131 (Daniel Dinh-Phuc Mai and Sven Stucki). There was no blinding concerning the authors' names 132 and affiliations, or the outcomes of the included studies. Titles and abstracts were evaluated first, 133 if necessary the full text was read to evaluate the eligibility. The same authors read all eligible 134 studies again in full text, independently, whereas non-eligible studies were excluded. Thereafter

135 the eligibility was discussed between all team members until a consensus was reached, under the 
136 guidance of the last author (Nikolaos Gkantidis). A record of all decisions made during this 137 process was retained.

\section{Data extraction}

139 The first and the last author performed data extraction independently and in duplicate, aiming to 140 extract from the eligible studies the following information:

141 - Methods: Author, title, year, objectives, and design of study.

142 - Participants: Patient number, age, and gender.

143 - Materials: 3D model acquisition method and time between serial models.

144 - Superimposition method: Type of superimposition reference areas or points and software with 145 specific settings used.

146 - Comparison/control group: Type and characteristics.

147 - Outcome: Type of outcome(s) and method of outcome assessment.

148 If necessary, the authors were contacted by email to request missing data. If the relevant

149 information was not provided, only the available information was used.

150 Assessment of heterogeneity

151 Study characteristics, similarity between types of participants, compared methods and assessed

152 outcomes were considered to define heterogeneity among studies.

153 Assessment of reporting bias

154 We conducted an accurate, but also broad enough search of multiple sources, including on-going 155 studies, to minimize potential reporting biases, such as publication bias and duplicate reports.

\section{Data synthesis}

157 A meta-analysis will be performed if there are at least two studies graded with an unclear or a 158 low risk of bias and additionally use similar methods or report the same outcomes measured on 159 similar data.

\section{Subgroup analysis}

161 Results will also be tested for the following factors, if possible:

$162 \cdot$ CBCT vs. CT data.

163 - Growing vs. non-growing patients. 
164 - Short-term (within 1 year) vs. medium/long-term (> 1 year) interval between serial models.

165 - Superimposition on the anterior cranial base vs. superimposition on maxillary structures vs.

166 superimposition on mandibular structures

167 Quality assessment

168 The quality of the selected studies was evaluated using the QUADAS-2 tool (Whiting, 2011).

169 This is a widely used tool to evaluate the diagnostic accuracy of methods in systematic reviews.

170 Using the QUADAS-2 tool the patient selection, the index test, the reference standard and the

171 flow and timing are evaluated regarding their risk of bias and applicability concerns. Usually,

172 gradings are shown in a table using happy (low risk) or sad smiles (high risk). In case an

173 evaluation is not possible, e.g. because of missing data, an interrogation mark is shown (unclear

174 risk). The total risk of bias or applicability concerns of each study correspond to the worst rating 175 given in the individual items assessed each time.

176 The quality assessment of all studies was performed by two authors (Daniel Dinh-Phuc Mai and

177 Nikolaos Gkantidis) independently. If there was a disagreement, a consensus was reached

178 through discussion among all authors. Studies graded with a high risk of bias were not to be

179 included in a meta-analysis.

180 RESULTS

181 Description of studies

182 The search results are shown in Figure 1. After searching various databases, 2'540 studies were 183 found. Seven additional studies were identified through hand searches. After removing the

184 duplicates, 832 studies remained. These studies were screened by reading the titles and abstracts.

185 Full-text reading of 24 studies was performed to evaluate the eligibility. Nine studies did not 186 match the review question and thus, they were excluded as irrelevant to the study topic.

187 Following the selection process 15 studies were included in this review.

188 All included studies used 3D skeletal-tissue superimposition techniques to assess morphological 189 changes in the craniofacial complex, the accuracy or precision of the applied processes, or the 190 agreement between different techniques as a primary outcome.

\section{Quality assessment}


192 The quality assessment of the included studies is provided in Table 1.

193 From the 15 included studies, 12 of these have shown a high total risk of bias, one a low risk of 194 bias, and 2 studies have shown an unclear risk of bias. Regarding the individual items 4 studies 195 have high, 7 low, and 4 unclear risk of bias in the patient selection. Regarding the index test, 8

196 studies have high, 6 low, and one unclear risk of bias. The reference standard of 9 studies shows 197 a high risk of bias, of 2 low, and of 4 unclear. The flow and timing of 2 studies has high, of 11 198 low, and of 2 unclear risk of bias.

199 Thirteen out of the 15 studies showed high total applicability concerns, 2 unclear and no study 200 had low applicability concerns. Concerning the individual items, 6 studies had high, 6 unclear 201 and 3 low applicability concerns in the patient selection. Regarding the index test, 9 studies had 202 high, one unclear and 5 low applicability concerns. The reference standard of 9 studies showed 203 high, of 3 unclear and of 3 low applicability concerns.

\section{Characteristics of the included studies}

205 One of the included studies utilized prospective radiographic image acquisition and $14 \mathrm{a}$ 206 retrospective one. Regarding the superimposition data generation and method comparison all 207 studies were prospective. Eight studies included only growing patients, 6 only non-growing and 2081 study both. None of the eligible studies was performed in patients with severe craniofacial 209 malformations, such as those related to systemic conditions, congenital anomalies, or syndromes. 210 Fourteen studies were performed on Cone Beam Computed Tomography (CBCT) and 1 on

211 Computed Tomography (CT) images. Eleven studies used voxel-based registration, 1 landmark212 based registration, and 3 compared different registration techniques. Concerning the area of 213 interest, 9 studies focused on the anterior cranial base and certain facial structures, 4 on 214 maxillary structures and 4 on mandibular structures.

215 The characteristics of the included studies are provided in detail in tables 2, 3, and 4.

\section{Results and Qualitative synthesis of the included studies}

217 The results of the included studies are shown in Table 4 and the conclusions and limitations in 218 Table 5. 
219 There was high heterogeneity among studies regarding the type of participants, sample size, 220 growth status, machines, acquisition parameters, superimposition techniques, assessment

221 techniques and outcomes measured. Therefore, no quantitative synthesis was performed.

222 For the qualitative synthesis, the included studies are categorized in four groups based on the

223 registration technique assessed: 1. voxel-based registration, 2. landmark-registration and 3.

224 comparison of different registration techniques, which include the surface-based registration.

\section{Voxel-based registration}

226 Eleven studies tested the voxel-based registration. Six of those studies included only growing 227 patients, 4 only non-growing and one study included both. Nine studies of this subgroup had

228 high, and 2 unclear risk of bias. Similarly, 9 studies had high and 2 unclear applicability

229 concerns. Six studies used cranial base structures as superimposition reference, whereas 2 studies 230 used maxillary and 4 mandibular sites.

231 Bazina et al. (Bazina et al., 2018) superimposed CBCTs of 31 non-growing patients on the

232 anterior cranial base to evaluate the reproducibility of Dolphin voxel-based superimposition and

233 its agreement with ITK-Snap+3D Slicer superimposition. The Dolphin 3D software seemed to

234 work properly, but the study showed important limitations, high risk of bias, and high

235 applicability concerns.

236 Cevidanes et al. (Cevidanes et al., 2005) tested the reproducibility of 3D cranial base

237 superimpositions for the evaluation of mandibular ramus changes in maxillary orthognathic 238 surgery patients. To verify reproducibility, changes from pre- to post-treatment were measured 239 on mandibular areas of 10 non-growing patients. The surgery was performed exclusively on the 240 maxilla and the assessments on the mandible. Hence, no or minimal changes are expected in the 241 mandible. Under these circumstances, the technique showed acceptable reproducibility, though

242 in certain cases the inter-observer variation was relatively high, compared to the limited original 243 changes. The study had unclear risk of bias and applicability concerns.

244 In another study, Cevidanes et al. (Cevidanes et al., 2009) performed 3D superimpositions on the 245 anterior cranial base to investigate the reproducibility of the technique for the evaluation of 246 overall facial changes in three growing patients. Nine regions distributed on the whole face were 247 assessed by three operators. Detailed results acquired by each operator were not reported and 248 only the ranges were provided. Within this limitation, this method seemed reproducible in 
249 growing patients. However, as the sample size was quite small and did not allow statistical 250 comparisons, no rigid conclusion can be made. This study showed high risk of bias and 251 applicability concerns.

252 Häner et al. (Häner et al., 2020) evaluated the trueness, reproducibility, and segmentation effect 253 on hard tissue outcomes using the Dolphin voxel-based superimposition. Fifteen growing 254 patients were included, and the superimposition was performed on the anterior cranial base. The 255 trueness of the voxel-based superimposition was assessed through visual inspection of 256 corresponding reference structures, and the intra and inter-operator reproducibility was assessed 257 through repeatedly superimposed 3D models. The superimposition technique exhibited adequate 258 performance in growing patients, in terms of efficiency, cranial base matching, and 259 reproducibility. The segmentation error was also acceptable in most cases. However, due to 260 certain limitations the study showed unclear risk of bias and applicability concerns.

261 Koerich et al. (Koerich et al., 2016) investigated the precision and the reproducibility of one 262 superimposition method in the maxilla and one in the mandible. As superimposition references 263 for the maxilla, they used two areas (zygomatic process; palate) and for the mandible three areas 264 (symphysis; corpus; part ramus). The sample for this study included two dry skulls and 15 non265 growing patients. Different machines and acquisition parameters were used in the dry skulls and 266 the actual patients. This technique has shown excellent precision and reproducibility, although 267 the evaluated regions are considered relatively unaltered. Surprisingly, the distances obtained 268 from the superimposition of the two dry skulls were higher than expected and than those 269 acquired from the superimposition of actual serial scans. This study had high risk of bias and 270 high applicability concerns.

271 Koerich et al. (Koerich et al., 2017) also assessed the precision and reproducibility of a 3D 272 mandibular voxel-based superimposition in 24 growing patients. To test the performance of this 273 technique, distances between serial models at five mandibular regions located at the outer surface 274 of the mandible were measured. Although the assessed structures were originally relatively 275 unaltered the inter-observer variation was larger than expected. Thus, this mandibular technique 276 showed moderate precision and reproducibility in the assessment of relatively unaltered 277 structures. The study had high risk of bias and high applicability concerns.

278 Nada et al. (Nada et al., 2011) evaluated the accuracy and reproducibility of a voxel-based 279 registration of $\mathrm{CBCT}$ models on two different regions: the anterior cranial base and the 
280 zygomatic arches. Data were collected from 16 non-growing patients. Changes were measured 281 afterwards on four anatomical regions, which were deemed stable: the anterior cranial base, the 282 forehead, the left zygomatic arch, and the right zygomatic arch. The accuracy and reproducibility 283 of this technique seems to be high, although the original changes measured were small. The 284 superimposition on the left zygomatic arch appears to be a valid alternative to that on the anterior 285 cranial base in non-growing patients. The added advantage is that it can be used in images with 286 smaller field of view, and thus, lower radiation. However, individual changes were not reported and only mean values were assessed. The study had high risk of bias and applicability concerns. Nguyen et al. (Nguyen et al., 2018) searched for stable anatomical regions in the mandible by superimposing CBCTs of growing patients on bony plates and miniscrews. They concluded that the chin and symphysis region might be anatomically stable, whereas the third molar region displayed a higher instability. However, among other limitations, the bone plates and screws were confirmed to be immobile clinically, but their stability in space was not tested. The study

293 had high risk of bias and high applicability concerns.

294 Ruellas et al. (Ruellas et al., 2016a) aimed to identify stable maxillary superimposition 295 references for growing patients. The precision and reproducibility of two different maxillary 296 regions were tested on a sample of 16 patients. To quantify changes distances between 297 corresponding landmarks at pre- and post-treatment models after registration were assessed.

298 However, the absence of comparative statistics and the evaluation of average effects of different 299 300 variables did not allow for a clear conclusion. The study had high risk of bias and high applicability concerns.

301 Ruellas et al. (Ruellas et al., 2016b) evaluated three reference regions for mandibular 302 superimposition using a sample of 16 growing patients. Following superimposition of the serial 303 scans and analysis of the distances between corresponding landmarks, the body of the mandible 304 seemed to show better agreement with direct measurements from a point considered stable, when compared to the modified Björk technique. The performance of the Björk technique was not reported in the study, due to software performance issues. The reporting of the results was poor, 307 since the presented mean values were outside of the provided limits of agreement. The study had 308 high risk of bias and high applicability concerns.

309 Weissheimer et al. (Weissheimer et al., 2015) also performed voxel-based superimposition on 310 the anterior cranial base in serial 3D CBCT models of growing and non-growing patients. The 
311 assessment of the accuracy was done through visual inspection of the congruence of the anterior

312 cranial base between serial models using colour coded distance maps. Through this, it was

313 established that the highest distance was less than $0.5 \mathrm{~mm}$. Thus, it seemed that the software

314 works properly and the anterior cranial base is a stable superimposition reference in both

315 growing and non-growing patients. However, the study has no descriptive or comparative

316 statistics. Merely data from two patients were shown. Thus, the study has shown high risk of bias

317 and applicability concerns.

\section{Landmark-based registration}

319 Lemieux et al. (Lemieux et al., 2014) evaluated the trueness of a maxillary superimposition plane

320 using the nasomaxillary complex as reference. CBCTs of 30 growing patients were

321 superimposed on a maxillary superimposition plane formed by the nasion, the bilateral

322 infraorbital foramina and the incisive foramen. However, the performance of this landmark-

323 derived maxillary plane cannot be assessed through the present methodology. The study is

324 graded with high risk of bias and high applicability concerns.

\section{Comparison of different registration techniques}

326 Since now, a single study compared the accuracy of voxel-based registration and surface-based

327 registration for the 3D assessment of surgical change following orthognathic surgery (Almukhtar

328 et al., 2014). The sample included only non-growing patients. The surface-based registration on

329 hard tissues was performed on the anterior cranial base; as for the registration on soft tissues, the

330 forehead and the eyes were selected. Regarding the voxel-based registration, the structures

331 described above were chosen, but in this case hard and soft tissues were used simultaneously as

332 superimposition references. The assessment of accuracy in this study was tested via

333 measurements on the anterior cranial base for the hard tissues and on the forehead for the soft

334 tissues. The mean absolute distances of surface models in hard tissues did not differed much

335 between the voxel and the surface-based registrations, but this was not the case for the soft

336 tissues. This can be attributed to the differences in the superimposition references used each

337 time. The study showed high risk of bias and applicability concerns.

338 Gkantidis et al. (Gkantidis et al., 2015) investigated the accuracy, precision, and reproducibility

339 of four surface-based and one landmark-based 3D superimposition technique. Pre-existing CT

340 data from eight non-growing patients were analysed by three operators. To confirm the accuracy 
341 of each technique, the congruence of serial models was measured in three areas that were

342 considered stable. For precision testing, the distances between four corresponding landmarks

343 were quantified. The whole procedure was repeated to test reproducibility. The superimposition

344 on the anterior cranial base showed acceptable outcomes that were comparable with the

345 superimposition on both zygomatic arches. The study concluded that the superimposition of 3D

346 surface models created from voxel data can provide accurate, precise, and reproducible results

347 when appropriate references are used. Since this study used CT data, a similar study on CBCT

348 data of non-growing patients would be required to confirm these findings. Therefore, this study

349 had low risk of bias, but high applicability concerns.

350 Ghoneima et al. (Ghoneima et al., 2017) evaluated the reproducibility of landmark-based,

351 surface-based, and voxel-based superimpositions, as well as their performance in matching

352 duplicated scans. They superimposed CBCTs of 20 growing patients. The superimposition area

353 for the landmark-based method was defined on seven homologous points on the frontal and

354 zygomatic bones, for the surface-based method on the anterior cranial base, as well as for the

355 voxel-based method. Regarding the results, the surface-based and voxel-based superimpositions

356 seemed to be reproducible, whereas the landmark-based superimposition was less reproducible.

357 Based on certain limitations the study was graded to have high risk of bias and applicability

358 concerns.

359 DiscuSSION

360 Due to the inherent limitations of 2D superimposition methods various scientific fields have

361 turned their focus to the more thorough and accurate 3D imaging techniques, and worked to

362 create more reliable, faster, and easy to handle software facilitating this purpose. This allowed

363 researchers and clinicians to work with real size and shape 3D representations of anatomical

364 structures. However, till today there is no single method that has been proved to be accurate,

365 easy to use, and is widely accepted for superimposing 3D craniofacial radiographic images. This

366 review performed a thorough, critical assessment of the recent literature and analysed 15

367 identified studies that tested one or more of the three available superimposition techniques for

368 this; namely, the voxel-based, the landmark-based, and the surface-based technique. Overall, the

369 study detected high heterogeneity and moderate study quality, emphasizing the urgent need for

370 further relevant research in this rapidly expanding field. 
371 The single previous systematic evaluation of the literature included six studies that were all 372 published prior to 2017 and regarded only the anterior cranial base (Ponce-Garcia et al., 2018).

373 In our review, we performed a more thorough selection process including all relevant studies for

374 the whole craniofacial area and we managed to include 15 studies, though still the vast majority

375 of these focuses on the anterior cranial base area.

376 For clarity reasons we divided the included studies in the following three major categories, based

377 on the type of superimposition tested: landmark-based registration, voxel-based registration, and

378 comparison of different registration techniques, which includes the surface-based registration.

379 Landmark-based superimposition is relatively simple to use and understand, but small errors in

380 the identification of landmarks may have a large negative impact on the results. This is especially

381 true if a limited number of landmarks is used, but only then the method is simple and easy

382 (Gkantidis et al., 2015; Becker et al., 2018). Only one study investigated exclusively a landmark-

383 based superimposition technique (Lemieux et al., 2014). This was graded as high risk of bias and

384 applicability concerns. Two further studies (Gkantidis et al., 2015; Ghoneima et al., 2017) that

385 compared the landmark-based superimposition to other superimposition techniques (voxel- or

386 surface-based) concluded that the landmark-based superimposition was inferior to the others.

387 Overall, there is a lack of well-designed studies to support the use of landmark-based

388 superimposition. The existing weak evidence indicates that this technique might be unreliable,

389 especially when few landmarks are used as superimposition reference. Thus, the use of

390 landmark-based superimposition remains questionable.

391 Most of the included studies (11/15) investigated a voxel-based superimposition technique

392 (Cevidanes et al., 2005, 2009; Nada et al., 2011; Weissheimer et al., 2015; Ruellas et al.,

393 2016a,b; Koerich et al., 2016, 2017; Bazina et al., 2018; Nguyen et al., 2018; Häner et al., 2020).

394 This type of superimposition utilizes the original volume generated from a 3D radiographic scan

395 and no further data processing is required prior to the superimposition. That might also be a

396 reason why most studies focused on this type of superimposition. Most of the studies that

397 investigated a voxel-based superimposition technique (6) used cranial base structures as

398 superimposition reference, whereas two studies used maxillary and four mandibular sites. Thus,

399 the cranial base is the most widely tested and supported reference for voxel-based

400 superimposition, but until now the quality of evidence for this ranges from low to moderate.

401 More work needs also to be performed to find alternative reference areas that might be 
402 applicable is smaller field of view scans, reducing the required radiation amount. So far, two 403 studies have investigated this issue (Nada et al., 2011; Gkantidis et al., 2015), but they both had 404 high applicability concerns. Regarding the maxillary and the mandibular areas the amount of 405 existing evidence is lower and of low quality. Overall, nine of the included studies in this 406 category had high risk of bias and high applicability concerns and two unclear. There is no study 407 graded with low risk of bias or low applicability concerns. Hence, there is an urgent need for 408 well-designed studies with low risk of bias and low applicability concerns to support the voxel409 based superimposition techniques.

410 There was no study that focused only on surface-based superimposition. Surface-based 411 registration compares the triangular representations of corresponding 3D surface geometries on 412 the models. This technique might show adequate accuracy, it is less sensitive and time413 consuming, and has increased post-processing capabilities (Gkantidis et al., 2015). Three studies 414 that compared different registration techniques (Almukhtar et al., 2014; Gkantidis et al., 2015; 415 Ghoneima et al., 2017) included a surface-based technique. Two of them had high risk of bias 416 and all of them had high applicability concerns. The study of Gkantidis et al. (Gkantidis et al., 417 2015) showed low risk of bias, but high applicability concerns, and did not support the use of 418 landmark-based superimposition but showed acceptable results for surface-based 419 superimposition. Ghoneima et al. (Ghoneima et al., 2017) did not recommend the use of 420 landmark-based superimposition as well, but they showed promising results for voxel-based and 421 surface-based superimposition. Almukhtar et al. (Almukhtar et al., 2014) provided similar and 422 promising results for voxel-based and surface-based superimposition of hard-tissues. Thus, the 423 three above studies support the surface-based superimposition on the anterior cranial base 424 structures. Two of them also support the voxel-based superimposition (Almukhtar et al., 2014; 425 Ghoneima et al., 2017), whereas other two do not support the landmark-based superimposition 426 (Gkantidis et al., 2015; Ghoneima et al., 2017). However, the quality of evidence for the above 427 outcomes ranges from moderate to low.

428 Overall the literature supports the use of voxel-based and surface-based superimposition 429 techniques, though the existing evidence is not yet strong. Because of the limited amount of 430 well-designed studies, further research is needed to confirm the present findings. It seems that 431 these techniques show better accuracy and are less operator-sensitive compared to the landmark432 based superimposition. A limitation of the surface-based registration is the lack of information 
433 concerning inner structures as only the surface information is available after processing.

434 Furthermore, an additional step is required to segment the surface model of interest from the 435 original 3D volume and this might induce error (Häner et al., 2020). The voxel-based registration 436 is applied to the original volumetric data derived from a $3 \mathrm{D}$ radiographic scan, and thus, this 437 might be advantageous in terms of less error prone steps required to achieve model registration. 438 However, after the registration of serial volumes, surface models are usually required for 439 thorough assessment and visualization of the results. Thus, this possible source of error is not 440 fully eliminated also through this method. Furthermore, the surface models are widely used in 441 various other scientific disciplines and in the industry, leading to well-developed methods and 442 software applications for data processing and evaluation. Thus, the acquisition of accurate 443 surface models from the original volume is quite important to take advantage of these 444 possibilities for data processing and visualisation and will also facilitate accurate surface model 445 superimposition techniques (Henninger et al., 2019).

446 Though a significant amount of studies was identified, a limitation of the present study is that the 447 heterogeneity of the included studies is high, and the quality of the available evidence is limited. 448 This can be attributed to the fact that the field has been developed in the last few years and 449 gained much attention only recently.

\section{CONCLUSION}

451 The fast evolution of 3D superimposition techniques has provided a key element in the toolkit of 452 relevant fields to evaluate craniofacial changes following growth or treatment. Due the high 453 heterogeneity and the moderate to low quality of the included studies, few valid conclusions can 454 be drawn. Most of the available studies had methodological shortcomings and high applicability 455 concerns. Therefore, no clear recommendation could be given at present for proper methods used 456 for 3D-superimposition of craniofacial skeletal structures. At the moment, certain voxel-based 457 and surface-based superimpositions seem to work properly and to be superior compared to 458 landmark-based superimposition. However, further research is necessary to develop and properly 459 validate these techniques on different samples, through studies with high quality and low 460 applicability concerns. 
461

462

463

464

465

466

467

468

469

470

471

472

473

474

475

476

477

478

479

480

481

482

483

484

485

486

487

488

489

490

491

492

493

494

495

496

497

498

499

500

501

502

503

504

505

506

\section{REFERENCES}

1. Afrand M, Ling CP, Khosrotehrani S, Flores-Mir C, Lagravère-Vich MO. 2014. Anterior cranial-base time-related changes: A systematic review. American Journal of Orthodontics and Dentofacial Orthopedics 146:21-32.e6. DOI: 10.1016/j.ajodo.2014.03.019.

2. AlHadidi A, Cevidanes L, Mol A, Ludlow J, Styner M. 2011. Comparison of two methods for quantitative assessment of mandibular asymmetry using cone beam computed tomography image volumes. Dentomaxillofacial Radiology 40:351-357. DOI: $10.1259 / \mathrm{dmfr} / 13993523$.

3. Almeida RC, Cevidanes LHS, Carvalho FAR, Motta AT, Almeida MAO, Styner M, Turvey T, Proffit WR, Phillips C. 2011. Soft tissue response to mandibular advancement using 3D CBCT scanning. International Journal of Oral and Maxillofacial Surgery 40:353-359. DOI: 10.1016/j.ijom.2010.11.018.

4. Almukhtar A, Ju X, Khambay B, McDonald J, Ayoub A. 2014. Comparison of the Accuracy of Voxel Based Registration and Surface Based Registration for 3D Assessment of Surgical Change following Orthognathic Surgery. PLoS ONE 9:e93402. DOI: 10.1371/journal.pone.0093402.

5. Bazina M, Cevidanes L, Ruellas A, Valiathan M, Quereshy F, Syed A, Wu R, Palomo JM. 2018. Precision and reliability of Dolphin 3-dimensional voxel-based superimposition. American Journal of Orthodontics and Dentofacial Orthopedics 153:599-606. DOI: 10.1016/j.ajodo.2017.07.025.

6. Becker K, Wilmes B, Grandjean C, Vasudavan S, Drescher D. 2018. Skeletally anchored mesialization of molars using digitized casts and two surface-matching approaches: Analysis of treatment effects. Journal of Orofacial Orthopedics / Fortschritte der Kieferorthopädie 79:11-18. DOI: 10.1007/s00056-017-0108-y.

7. Björk A. 1969. Prediction of mandibular growth rotation. American Journal of Orthodontics 55:585-599. DOI: 10.1016/0002-9416(69)90036-0.

8. Björk A, Skieller V. 1977. Growth of the Maxilla in Three Dimensions as Revealed Radiographically by the Implant Method. British Journal of Orthodontics 4:53-64. DOI: 10.1179/bjo.4.2.53.

9. Buschang PH, LaPalme L, Tanguay R, Demirjian A. 1986. The technical reliability of superimposition on cranial base and mandibular structures. The European Journal of Orthodontics 8:152-156. DOI: 10.1093/ejo/8.3.152.

10. Cevidanes L, Bailey L, Tucker G, Styner M, Mol A, Phillips C, Proffit W, Turvey T. 2005. Superimposition of 3D cone-beam CT models of orthognathic surgery patients. Dentomaxillofacial Radiology 34:369-375. DOI: 10.1259/dmfr/17102411.

11. Cevidanes LHC, Heymann G, Cornelis MA, DeClerck HJ, Tulloch JFC. 2009. Superimposition of 3-dimensional cone-beam computed tomography models of growing patients. American Journal of Orthodontics and Dentofacial Orthopedics 136:94-99. DOI: 10.1016/j.ajodo.2009.01.018.

12. Cevidanes LHC, Motta A, Proffit WR, Ackerman JL, Styner M. 2010. Cranial base superimposition for 3-dimensional evaluation of soft-tissue changes. American Journal of Orthodontics and Dentofacial Orthopedics 137:S120-S129. DOI: 10.1016/j.ajodo.2009.04.021.

13. Ghoneima A, Cho H, Farouk K, Kula K. 2017. Accuracy and reliability of landmarkbased, surface-based and voxel-based 3D cone-beam computed tomography

PeerJ reviewing PDF | (2020:03:46530:1:2:NEW 6 May 2020) 
507

508

509

510

511

512

513

514

515

516

517

518

519

520

521

522

523

524

525

526

527

528

529

530

531

532

533

534

535

536

537

538

539

540

541

542

543

544

545

546

547

548

549

550

551

552

superimposition methods. Orthodontics \& Craniofacial Research 20:227-236. DOI: 10.1111/ocr.12205.

14. Gkantidis N, Schauseil M, Pazera P, Zorkun B, Katsaros C, Ludwig B. 2015. Evaluation of 3-Dimensional Superimposition Techniques on Various Skeletal Structures of the Head Using Surface Models. PLOS ONE 10:e118810. DOI: 10.1371/journal.pone.0118810.

15. Grauer D, Cevidanes LSH, Proffit WR. 2009. Working with DICOM craniofacial images. American Journal of Orthodontics and Dentofacial Orthopedics 136:460-470. DOI: 10.1016/j.ajodo.2009.04.016.

16. Häner ST, Kanavakis G, Matthey F, Gkantidis N. 2020. Voxel-based superimposition of serial craniofacial CBCTs: Reliability, reproducibility and segmentation effect on hard-tissue outcomes. Orthodontics \& Craniofacial Research 23:92-101. DOI: 10.1111/ocr.12347.

17. Henninger E, Vasilakos G, Halazonetis D, Gkantidis N. 2019. The effect of regular dental cast artifacts on the 3D superimposition of serial digital maxillary dental models. Scientific Reports 9:10501. DOI: 10.1038/s41598-019-46887-1.

18. Koerich L, Burns D, Weissheimer A, Claus JDP. 2016. Three-dimensional maxillary and mandibular regional superimposition using cone beam computed tomography: a validation study. International Journal of Oral and Maxillofacial Surgery 45:662-669. DOI: 10.1016/j.ijom.2015.12.006.

19. Koerich L, Weissheimer A, de Menezes LM, Lindauer SJ. 2017. Rapid 3D mandibular superimposition for growing patients. The Angle Orthodontist 87:473-479. DOI: 10.2319/072316-574.1.

20. Lemieux G, Carey JP, Flores-Mir C, Secanell M, Hart A, Dietrich N, Lagravère-Vich MO. 2014. Three-dimensional cephalometric superimposition of the nasomaxillary complex. American Journal of Orthodontics and Dentofacial Orthopedics 146:758-764. DOI: 10.1016/j.ajodo.2014.08.014.

21. Nada RM, Maal TJJ, Breuning KH, Bergé SJ, Mostafa YA, Kuijpers-Jagtman AM. 2011. Accuracy and Reproducibility of Voxel Based Superimposition of Cone Beam Computed Tomography Models on the Anterior Cranial Base and the Zygomatic Arches. PLoS ONE 6:e16520. DOI: 10.1371/journal.pone.0016520.

22. Nguyen T, Cevidanes L, Franchi L, Ruellas A, Jackson T. 2018. Three-dimensional mandibular regional superimposition in growing patients. American Journal of Orthodontics and Dentofacial Orthopedics 153:747-754. DOI: 10.1016/j.ajodo.2017.07.026.

23. Ponce-Garcia C, Lagravere-Vich M, Cevidanes LHS, de Olivera Ruellas AC, Carey J, Flores-Mir C. 2018. Reliability of three-dimensional anterior cranial base superimposition methods for assessment of overall hard tissue changes: A systematic review. The Angle Orthodontist 88:233-245. DOI: 10.2319/071217-468.1.

24. Ruellas AC de O, Huanca Ghislanzoni LT, Gomes MR, Danesi C, Lione R, Nguyen T, McNamara Jr JA, Cozza P, Franchi L, Cevidanes LHS. 2016a. Comparison and reproducibility of 2 regions of reference for maxillary regional registration with conebeam computed tomography. American Journal of Orthodontics and Dentofacial Orthopedics 149:533-542. DOI: 10.1016/j.ajodo.2015.09.026.

25. Ruellas AC de O, Yatabe MS, Souki BQ, Benavides E, Nguyen T, Luiz RR, Franchi L, Cevidanes LHS. 2016b. 3D Mandibular Superimposition: Comparison of Regions of 
553

554

555

556

557

558

559

560

561

562

563

564

565

566

Reference for Voxel-Based Registration. PLOS ONE 11:e0157625. DOI: 10.1371/journal.pone.0157625.

26. Stucki S, Gkantidis N. 2019. Assessment of techniques used for superimposition of maxillary and mandibular 3D surface models to evaluate tooth movement: a systematic review. European Journal of Orthodontics pii: cjz075. DOI: 10.1093/ejo/cjz075. [Epub ahead of print]

27. Weissheimer A, Menezes LM, Koerich L, Pham J, Cevidanes LHS. 2015. Fast threedimensional superimposition of cone beam computed tomography for orthopaedics and orthognathic surgery evaluation. International Journal of Oral and Maxillofacial Surgery 44:1188-1196. DOI: 10.1016/j.ijom.2015.04.001.

28. Whiting PF. 2011. QUADAS-2: A Revised Tool for the Quality Assessment of Diagnostic Accuracy Studies. Annals of Internal Medicine 155:529. DOI: 10.7326/00034819-155-8-201110180-00009. 
Figure 1 


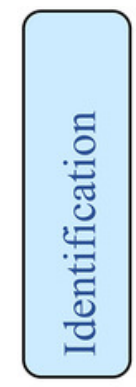

Records identified through database searching

$$
\text { ( } \left.\mathrm{n}=2{ }^{\prime} 540\right)
$$
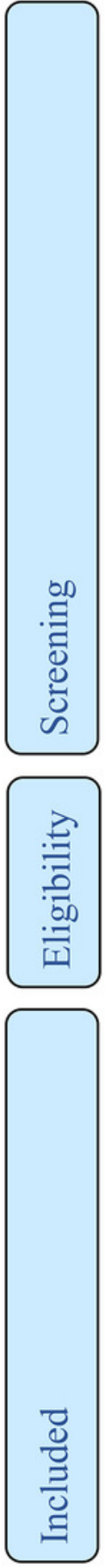

Additional records identified through other sources

$$
(n=7)
$$

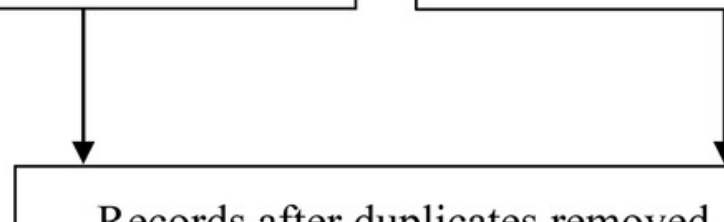

Records after duplicates removed

$$
(\mathrm{n}=832)
$$

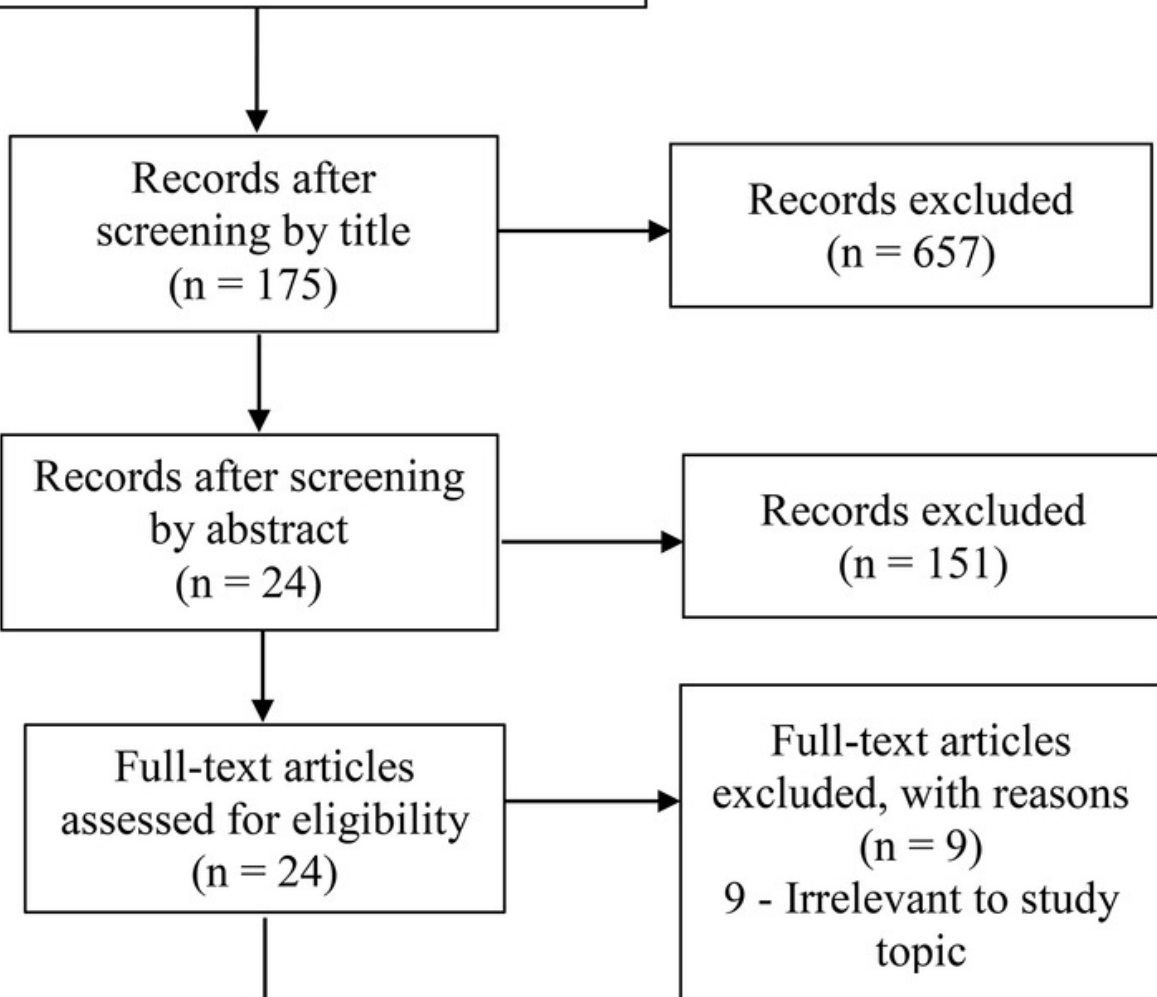

Studies included in qualitative synthesis

$$
(\mathrm{n}=15)
$$

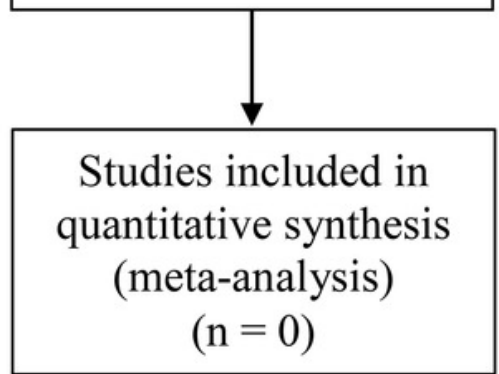




\section{Table $\mathbf{1}$ (on next page)}

Happy face $=$ low risk of bias/low applicability concerns; Sad face $=$ high risk of bias/high applicability concerns; ? = unclear risk of bias/unclear applicability concerns 
1 Table 1 Quality assessment of the included studies through the QUADAS-2 tool.

\begin{tabular}{|c|c|c|c|c|c|c|c|c|c|}
\hline \multirow[b]{2}{*}{ Study } & \multicolumn{5}{|c|}{ Risk of Bias } & \multicolumn{4}{|c|}{ Applicability Concerns } \\
\hline & $\begin{array}{c}\text { Patient } \\
\text { Selection }\end{array}$ & Index Test & $\begin{array}{l}\text { Reference } \\
\text { Standards }\end{array}$ & $\begin{array}{l}\text { Flow \& } \\
\text { Timing }\end{array}$ & $\begin{array}{c}\text { Total Risk } \\
\text { of Bias }\end{array}$ & $\begin{array}{l}\text { Patient } \\
\text { Selection }\end{array}$ & $\begin{array}{c}\text { Index } \\
\text { Test }\end{array}$ & $\begin{array}{l}\text { Reference } \\
\text { Standards }\end{array}$ & $\begin{array}{c}\text { Total Applicability } \\
\text { Concerns }\end{array}$ \\
\hline $\begin{array}{l}\text { Almukhtar et al., } \\
\text { PLoS One (2014) }\end{array}$ & ;) & ;) & : & (;) & : & (;) & : & : & : \\
\hline $\begin{array}{l}\text { Bazina et al., } \\
\text { Am J Orthod Dentofacial Orthop (2018) }\end{array}$ & ;) & : & : & ;) & : & ;) & : & :) & : \\
\hline $\begin{array}{l}\text { Cevidanes et al., } \\
\text { Dentomaxillofac Radiol (2005) }\end{array}$ & $?$ & ;) & ;) & ;) & $?$ & $?$ & ;) & ;) & $?$ \\
\hline $\begin{array}{l}\text { Cevidanes et al., } \\
\text { Am J Orthod Dentofacial Orthop (2009) }\end{array}$ & $:$ & ;) & $?$ & ;) & : & :) & ;) & $?$ & : \\
\hline $\begin{array}{l}\text { Gkantidis et al., } \\
\text { PLoS One (2015 }\end{array}$ & ;) & ;) & ;) & ;) & ;) & : & ;) & ;) & : \\
\hline $\begin{array}{l}\text { Ghoneima et al., } \\
\text { Orthod Craniofac Res (2017) }\end{array}$ & $:$ & 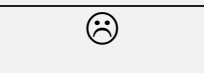 & $\because$ & : & : & $?$ & 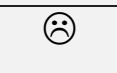 & 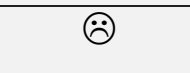 & : \\
\hline $\begin{array}{l}\text { Häner et al., } \\
\text { Orthod Craniofac Res (2019) }\end{array}$ & $?$ & $?$ & $?$ & ;) & $?$ & $?$ & $?$ & $?$ & $?$ \\
\hline $\begin{array}{l}\text { Koerich et al., } \\
\text { Int J Oral Maxillofac Surg (2016) }\end{array}$ & ;) & ;) & : & (;) & : & (2) & (;) & (:) & (:) \\
\hline $\begin{array}{l}\text { Koerich et al., } \\
\text { Angle Orthod (2017) }\end{array}$ & $?$ & (;) & : & $?$ & (:) & (:) & ;:) & : & : \\
\hline $\begin{array}{l}\text { Lemieux et al., } \\
\text { Am J Orthod Dentofacial Orthop (2014) }\end{array}$ & $?$ & : & (:) & $?$ & : & $?$ & : & (:) & : \\
\hline $\begin{array}{l}\text { Nada et al., } \\
\text { PLoS One (2011) }\end{array}$ & (;) & : & $?$ & (;) & (:) & $?$ & (:) & (;) & (:) \\
\hline $\begin{array}{l}\text { Nguyen et al., } \\
\text { Am J Orthod Dentofacial Orthop (2017) }\end{array}$ & : & : & : & ;) & (:) & (:) & (2) & (:) & : \\
\hline $\begin{array}{l}\text { Ruellas et al., } \\
\text { Am J Orthod Dentofacial Orthop (2016a) }\end{array}$ & (;) & (:) & : & (:) & (2) & (;) & : & (:) & : \\
\hline $\begin{array}{l}\text { Ruellas et al., } \\
\text { PLoS One (2016b) }\end{array}$ & (;) & (:) & : & : & (:) & $?$ & : & (:) & : \\
\hline $\begin{array}{l}\text { Weissheimer et al., } \\
\text { Int J Oral Maxillofac Surg (2015) }\end{array}$ & : & : & $?$ & (;) & : & : & (:) & $?$ & (:) \\
\hline
\end{tabular}

2 -) = low risk of bias/low applicability concerns; $; *$ = high risk of bias/high applicability concerns; ? = unclear risk of bias/unclear applicability concerns 
Table 2 (on next page) 
1 Table 2 Main general characteristics of the included studies.

\begin{tabular}{|c|c|c|c|c|c|c|}
\hline Study & Study objectives & Study design & Type of participants & Sample size & Growth status & Time span \\
\hline $\begin{array}{l}\text { Almukhtar et al., } \\
\text { PLoS One (2014) }\end{array}$ & $\begin{array}{l}\text { To compare the trueness of voxel-based } \\
\text { registration and surface-based registration for } \\
3 \mathrm{D} \text { assessment of surgical change following } \\
\text { orthognathic surgery. }\end{array}$ & $\begin{array}{l}\text { Retrospective } \\
\text { (radiographs) // } \\
\text { prospective } \\
\text { methodological study }\end{array}$ & $\begin{array}{l}\text { pre- \& post-orthognatic surgery } \\
\text { CBCTs }\end{array}$ & 31 Patients & Non-growing & $\min .6$ months \\
\hline $\begin{array}{l}\text { Bazina et al., } \\
\text { Am J Orthod } \\
\text { Dentofacial Orthop } \\
\text { (2018) }\end{array}$ & $\begin{array}{l}\text { To evaluate the reproducibility of Dolphin voxel- } \\
\text { based superimposition and its agreement with } \\
\text { ITK-Snap+3D Slicer superimposition. }\end{array}$ & $\begin{array}{l}\text { Retrospective (Scans) } \\
\text { // prospective } \\
\text { methodological study }\end{array}$ & $\begin{array}{l}\text { Pre- and post-1-jaw or 2-jaw } \\
\text { orthognatic surgery including LeFort I } \\
\text { osteotomy, bilateral sagittal split } \\
\text { osteotomy, or genioplasty CBCTs }\end{array}$ & 31 Patients & $\begin{array}{l}\text { Non-growing }(21 \pm 8 \text { years, } \\
\text { range: } 15-47 \text { years })\end{array}$ & $\begin{array}{l}13 \text { months (within } 1 \text { month prior } \\
\text { surgery and } 12 \text { months after } \\
\text { surgery) }\end{array}$ \\
\hline $\begin{array}{l}\text { Cevidanes et al., } \\
\text { Dentomaxillofac } \\
\text { Radiol (2005) }\end{array}$ & $\begin{array}{l}\text { To determine the reproducibility of voxel-based } \\
\text { superimposition to evaluate mandibular ramus } \\
\text { changes in maxillary orthognatic surgery } \\
\text { patients. }\end{array}$ & $\begin{array}{l}\text { Prospective } \\
\text { methodological study }\end{array}$ & $\begin{array}{l}\text { Pre- and post-orthognatic surgery } \\
\text { CBCTs }\end{array}$ & 10 Patients & Non-growing & 1 week \\
\hline $\begin{array}{l}\text { Cevidanes et al., } \\
\text { Am J Orthod } \\
\text { Dentofacial Orthop } \\
\text { (2009) }\end{array}$ & $\begin{array}{l}\text { To determine the reproducibility of voxel-based } \\
\text { superimpositions to evaluate overall facial } \\
\text { changes in growing patients. }\end{array}$ & $\begin{array}{l}\text { Retrospective } \\
\text { (radiographs) // } \\
\text { prospective } \\
\text { methodological study }\end{array}$ & $\begin{array}{l}\text { Pre- and post-orthopedic treatment } \\
\text { of Class III malocclusion with } \\
\text { miniplates CBCTs }\end{array}$ & 3 Patients & $\begin{array}{l}\text { Growing (mean age: } 11.4 \\
\text { years) }\end{array}$ & 1 year \\
\hline $\begin{array}{l}\text { Gkantidis et al., } \\
\text { PLoS One (2015) }\end{array}$ & $\begin{array}{l}\text { To test the applicability, trueness, precision, } \\
\text { and reproducibility of various } 3 \mathrm{D} \\
\text { superimposition techniques for radiographic } \\
\text { data, transformed to triangulated surface data. }\end{array}$ & $\begin{array}{l}\text { Retrospective } \\
\text { (radiographs) // } \\
\text { prospective } \\
\text { methodological study }\end{array}$ & $\begin{array}{l}\text { Pre- and post-rapid maxillary } \\
\text { expansion CTs }\end{array}$ & 8 Patients & $\begin{array}{l}\text { Non-growing (median age: } \\
16.2 \text { years) }\end{array}$ & $10-23$ days \\
\hline $\begin{array}{l}\text { Ghoneima et al., } \\
\text { Orthod Craniofac } \\
\text { Res (2017) }\end{array}$ & $\begin{array}{l}\text { To evaluate the reproducibility of landmark- } \\
\text { based, surface-based and voxel-based } \\
\text { superimpositions, as well as their performance } \\
\text { in matching duplicated scans. }\end{array}$ & $\begin{array}{l}\text { Retrospective (CBCT } \\
\text { images) // prospective } \\
\text { methodological study }\end{array}$ & $\begin{array}{l}\text { Pre- and post-correction of Class II } \\
\text { malocclusion with Herbst appliance } \\
\text { CBCTs }\end{array}$ & $\begin{array}{l}20 \text { Patients ( } 9 \\
\text { males, } 11 \text { females) }\end{array}$ & $\begin{array}{l}\text { Growing (range: 8-15 } \\
\text { years) }\end{array}$ & NA \\
\hline $\begin{array}{l}\text { Häner et al., } \\
\text { Orthod Craniofac } \\
\text { Res (2019) }\end{array}$ & $\begin{array}{l}\text { To evaluate the trueness, reproducibility and } \\
\text { segmentation effect on hard tissue outcomes } \\
\text { using voxel-based superimposition. }\end{array}$ & $\begin{array}{l}\text { Retrospective (CBCT } \\
\text { images) // prospective } \\
\text { methodological study }\end{array}$ & $\begin{array}{l}\text { Orthodontic patients without } \\
\text { accounting for performed treatment } \\
\text { or skeletal growth pattern CBCTs }\end{array}$ & $\begin{array}{l}15 \text { Patients ( } 8 \\
\text { males, } 7 \text { females) }\end{array}$ & $\begin{array}{l}\text { Growing }(11.75 \pm 0.59 \\
\text { years) }\end{array}$ & $1.69 \pm 0.37$ years \\
\hline $\begin{array}{l}\text { Koerich et al., } \\
\text { Int J Oral Maxillofac } \\
\text { Surg (2016) }\end{array}$ & $\begin{array}{l}\text { To evaluate the reproducibility of a } \\
\text { superimposition method for the maxilla and } \\
\text { mandible in non-growing patients. }\end{array}$ & $\begin{array}{l}\text { Retrospective } \\
\text { (radiographs) // } \\
\text { prospective } \\
\text { methodological study }\end{array}$ & $\begin{array}{l}\text { 1. Two serial CBCT images of dry } \\
\text { skulls after changing their position } \\
\text { 2. Two serial CBCT images of } \\
\text { orthodontic or wisdom tooth surgery } \\
\text { patients }\end{array}$ & $\begin{array}{l}\text { 1. } 2 \text { Dry skulls } \\
\text { 2. } 15 \text { Patients }\end{array}$ & Non-growing & $\begin{array}{l}12.3 \text { months (range: } 4-24 \\
\text { months) }\end{array}$ \\
\hline
\end{tabular}


3 Table 2 Continued

\begin{tabular}{|c|c|c|c|c|c|c|}
\hline Study & Study objectives & Study designs & Type of participants & Sample size & Growth & Time span \\
\hline $\begin{array}{l}\text { Koerich et al., } \\
\text { Angle Orthod } \\
\text { (2017) }\end{array}$ & $\begin{array}{l}\text { To evaluate the reproducibility of a voxel-based } \\
\text { superimposition of the mandible in growing } \\
\text { patients. }\end{array}$ & $\begin{array}{l}\text { Retrospective (scans) // } \\
\text { prospective } \\
\text { methodological study }\end{array}$ & $\begin{array}{l}\text { Pre- and post-rapid palatal } \\
\text { expansion CBCTs }\end{array}$ & 24 Patients & $\begin{array}{l}\text { Growing (mean age: } 10.8 \\
\pm 1.7 \text { years) }\end{array}$ & $16 \pm 2.9$ months \\
\hline $\begin{array}{l}\text { Lemieux et al., } \\
\text { Am J Orthod } \\
\text { Dentofacial Orthop } \\
\text { (2014) }\end{array}$ & $\begin{array}{l}\text { To evaluate the trueness of a maxillary } \\
\text { superimposition plane using the nasomaxillary } \\
\text { complex as reference. }\end{array}$ & $\begin{array}{l}\text { Retrospective (CBCT } \\
\text { images) // prospective } \\
\text { methodological study }\end{array}$ & $\begin{array}{l}\text { Pre- and post-rapid palatal } \\
\text { expansion CBCTs }\end{array}$ & 30 Patients & Growing (dental age of 12) & within 12 months \\
\hline $\begin{array}{l}\text { Nada et al., } \\
\text { PLoS One (2011) }\end{array}$ & $\begin{array}{l}\text { To evaluate the trueness and reproducibility of } \\
\text { a semi-automated voxel-based registration on } \\
\text { two regions: } 1 \text {. anterior cranial base and } 2 . \\
\text { zygomatic arches }\end{array}$ & $\begin{array}{l}\text { Retrospective } \\
\text { (radiographs) // } \\
\text { prospective } \\
\text { methodological study }\end{array}$ & $\begin{array}{l}\text { Pre- and-post-orthognatic surgery } \\
\text { CBCTs }\end{array}$ & 16 Patients & $\begin{array}{l}\text { Non-growing (mean age: } 26 \\
\pm 9 \text { years) }\end{array}$ & $18 \pm 4.6$ months \\
\hline $\begin{array}{l}\text { Nguyen et al., } \\
\text { Am J Orthod } \\
\text { Dentofacial Orthop } \\
\text { (2017) }\end{array}$ & $\begin{array}{l}\text { 1. To identify stable anatomical regions in the } \\
\text { mandible. } \\
\text { 2. To evaluate the reproducibility of the } \\
\text { chin+symphysis registration. }\end{array}$ & $\begin{array}{l}\text { Retrospective (CBCT } \\
\text { images) // prospective } \\
\text { methodological study }\end{array}$ & $\begin{array}{l}\text { 1. CBCTs of } 20 \text { Class III patients } \\
\text { with bone plates and screws in the } \\
\text { mandibular anterior area } \\
\text { 2. Pre- and post-correction of Class } \\
\text { II with Herbst appliances CBCTs ( } \mathrm{n}= \\
\text { 10); Pre- and post-correction of } \\
\text { Class II with elastics CBCTs }(\mathrm{n}= \\
\text { 10); Pre- and post-correction of } \\
\text { Class III with bone anchors CBCTs } \\
(\mathrm{n}=5)\end{array}$ & 25 Patients & $\begin{array}{l}\text { Growing (mean age: } 12.7 \pm \\
1.4 \text { years) }\end{array}$ & $\begin{array}{l}\text { 1. } 1.2 \text { years } \\
2.12 .6 \pm 0.9 \text { months }\end{array}$ \\
\hline $\begin{array}{l}\text { Ruellas et al., } \\
\text { Am J Orthod } \\
\text { Dentofacial Orthop } \\
(2016 a)\end{array}$ & $\begin{array}{l}\text { To evaluate the differences between voxel- } \\
\text { based registration on } 2 \text { regions of the maxilla } \\
\text { (1. Maxillary region and } 2 \text {. Palate and } \\
\text { Infrazygomatic region) and the reproducibility of } \\
\text { each technique }\end{array}$ & $\begin{array}{l}\text { Retrospective } \\
\text { (radiographs) // } \\
\text { prospective } \\
\text { methodological study }\end{array}$ & $\begin{array}{l}\text { Pre- and post-rapid maxillary } \\
\text { expansion for crossbite correction ( } n \\
=8 \text { ) and Pre- and post-correction of } \\
\text { Class II malocclusion with Herbst } \\
\text { appliance }(n=8)\end{array}$ & 16 Patients & Growing $(9-13$ years $)$ & 6 months \\
\hline $\begin{array}{l}\text { Ruellas et al., } \\
\text { PLoS One (2016b) }\end{array}$ & $\begin{array}{l}\text { To evaluate superimposition of serial } \\
\text { mandibular models on } 3 \text { reference regions } \\
\text { (Björk, modified Björk and mandibular body) as } \\
\text { compared to directly measured changes in } \\
\text { interlandmark distances. }\end{array}$ & $\begin{array}{l}\text { Retrospective } \\
\text { (radiographs) // } \\
\text { prospective } \\
\text { methodological study }\end{array}$ & NA & 16 Patients & growing ( $9-13$ years) & min. 18 months \\
\hline $\begin{array}{l}\text { Weissheimer et al., } \\
\text { Int J Oral Maxillofac } \\
\text { Surg (2015) }\end{array}$ & $\begin{array}{l}\text { To evaluate the trueness of a voxel-based } \\
\text { superimposition technique using the anterior } \\
\text { cranial base as reference for growing and non- } \\
\text { growing patients }\end{array}$ & $\begin{array}{l}\text { Retrospective } \\
\text { (radiographs) // } \\
\text { prospective } \\
\text { methodological study }\end{array}$ & $\begin{array}{l}\text { 1. Pre-treated images reoriented and } \\
\text { superimposed on the original }(n= \\
\text { 10) } \\
\text { 2. Pre- and post-orthognatic surgery } \\
(n=4) \\
\text { 3. Pre- and post-rapid palatal } \\
\text { expansion }(n=4) \\
\text { Time span: } 1 \text { year }\end{array}$ & 18 Patients & $\begin{array}{l}\text { 1. Growing ( } 11.4 \pm 1 \text { year) } \\
\text { 2. Non-growing }(26.3 \pm 5.7 \\
\text { years) } \\
\text { 3. Growing ( } 9.5 \pm 1.8 \text { years) }\end{array}$ & 1 year \\
\hline
\end{tabular}


Table 3 (on next page) 
1 Table 3 Main superimposition-related characteristics of the included studies.

\begin{tabular}{|c|c|c|c|c|c|c|}
\hline Study & Superimposition methods & References & $\begin{array}{l}\text { No of } \\
\text { Operators }\end{array}$ & Machines & Acquisition parameters & Software \\
\hline $\begin{array}{l}\text { Almukhtar et al., } \\
\text { PLoS One (2014) }\end{array}$ & $\begin{array}{l}\text { Voxel-based registration } \\
\text { (iterative best match of grey } \\
\text { scale intensities) } \\
\text { Surface-based registration } \\
\text { (iterative closest point) }\end{array}$ & $\begin{array}{l}\text { VBR: Anterior cranial base (extended } \\
\text { to involve the frontal bone) and } \\
\text { forehead region (including the forehead } \\
\text { and the eyes) } \\
\text { SBR: Anterior cranial base (for the } \\
\text { hard tissue) and forehead region (for } \\
\text { the soft tissue) }\end{array}$ & NA & $\begin{array}{l}\text { CBCT: i-CAT Classic } \\
\text { (Imaging Sciences, } \\
\text { Hatfield, UK) }\end{array}$ & NA & $\begin{array}{l}\text { Maxilim software (Medicim-Medical Image } \\
\text { Computing, Belgium) for voxel-based registration } \\
\text { (VBR). } \\
\text { VRMesh software (VirtualGrid, Bellevue City, WA) } \\
\text { for surface-based registration (SBR). }\end{array}$ \\
\hline $\begin{array}{l}\text { Bazina et al., } \\
\text { Am J Orthod } \\
\text { Dentofacial Orthop } \\
\text { (2018) }\end{array}$ & $\begin{array}{l}\text { Voxel-based Registration } \\
\text { (approximation using } 3 \\
\text { landmarks located at the right } \\
\text { and left frontozygomatic sutures } \\
\text { and the left mental foramen) }\end{array}$ & $\begin{array}{l}\text { Voxel-based Registration (iterative best } \\
\text { match of grey scale intensities) }\end{array}$ & 1 & $\begin{array}{l}\text { CBCT: CB MercuRay } \\
\text { scanner (Hitachi } \\
\text { Medical Systems } \\
\text { America Inc, } \\
\text { Twinsburg, OH) }\end{array}$ & $\begin{array}{l}\text { Tube voltage: } 120 \mathrm{kVp} \text {; Tube } \\
\text { current: } 15 \mathrm{~mA} ; \text { FOV: } 12 \text {-in; } \\
\text { Grey scale } 4006 ; \text {; Voxel size: } \\
0.38 \mathrm{~mm} 3 \text {; Exposure: } 9.5 \mathrm{~s}\end{array}$ & $\begin{array}{l}\text { 1. Dolphin 3D software (version 11.8.06.15 } \\
\text { premium; Dolphin Imaging, Chatsworth, Calif) for } \\
\text { the registration of T2 CBCT image to T1. } \\
\text { 2. ITK-SNAP software program (version } 3.0 .0 ; \\
\text { http://www.itksnap.org) and 3D Slicer (version } \\
\text { 4.4.0; http://www.slicer.org) for DICOM files } \\
\text { conversion, segmentation of the area of cranial } \\
\text { base and image registration. }\end{array}$ \\
\hline $\begin{array}{l}\text { Cevidanes et al., } \\
\text { Dentomaxillofac } \\
\text { Radiol (2005) }\end{array}$ & $\begin{array}{l}\text { Voxel-based Registration } \\
\text { (iterative best match of grey } \\
\text { scale intensities) }\end{array}$ & Cranial base & 3 & $\begin{array}{l}\text { CBCT: NewTom } 9000 \\
\text { (Aperio Services LLC, } \\
\text { Sarasota, FL, 34236) }\end{array}$ & FOV: $23 \times 23 \mathrm{~cm}$; Exposure: $70 \mathrm{~s}$ & $\begin{array}{l}\text { MIRIT Software for the fully automated rigid } \\
\text { registration. } \\
\text { VALMET Software for the 3D models comparison. }\end{array}$ \\
\hline $\begin{array}{l}\text { Cevidanes et al., } \\
\text { Am J Orthod } \\
\text { Dentofacial Orthop } \\
\text { (2009) }\end{array}$ & $\begin{array}{l}\text { Voxel-based Registration } \\
\text { (iterative best match of grey } \\
\text { scale intensities) }\end{array}$ & Anterior cranial base & 3 & $\begin{array}{l}\text { CBCT: iCat (Imaging } \\
\text { Sciences } \\
\text { International, Hatfield, } \\
\text { PA) }\end{array}$ & $\begin{array}{l}\text { FOV: } 16 \times 22 \mathrm{~cm} \text {; Voxel size: } 0.5 \\
\text { mm3; Exposure: } 40 \mathrm{~s}\end{array}$ & $\begin{array}{l}\text { Imagine software } \\
\text { (http://ia.unc.edu/dev/download/imagine/index.ht } \\
\text { m) for the rigid registration. }\end{array}$ \\
\hline $\begin{array}{l}\text { Gkantidis et al., } \\
\text { PLoS One (2015 }\end{array}$ & $\begin{array}{l}\text { Surface-based registration } \\
\text { (iterative closest point) }\end{array}$ & $\begin{array}{l}\text { 1. Three point registration (3P); } 2 \text {. One } \\
\text { zygomatic arch (1Z); } 3 \text {. Both zygomatic } \\
\text { arches (BZ); } 4 \text {. Anterior cranial base } \\
\text { (AC: body and small wing of the } \\
\text { sphenoid bone and part of the bottom } \\
\text { of the anterior cranial fossa); } 5 \text {. } \\
\text { Anterior cranial base + Foramen } \\
\text { magnum (middle posterior part of the } \\
\text { edge of the foramen magnum) (AC+F) }\end{array}$ & 3 & $\begin{array}{l}\text { CT: Philipps Brillance } \\
16 \text { CT Scanner }\end{array}$ & $\begin{array}{l}\text { Tube voltage: } 120 \mathrm{kV} ; \text { Tube } \\
\text { current: } 293 \mathrm{~mA} ; \text { FOV: } 21 \times 21 \times 12 \\
\text { cm; Voxel size: } 0.3 \mathrm{~mm} 3 ; \\
\text { Exposure: } 2.5 \mathrm{~s} \text {; Slice thickness: } \\
0.8 \mathrm{~mm} \text {; Spacing between slices: } \\
0.4 \mathrm{~mm} \text {; Spatial resolution: } 16 \\
\mathrm{Ip} / \mathrm{cm}\end{array}$ & $\begin{array}{l}\text { Geomagic Qualify } 2012 \text { software for Windows } \\
\text { (Geomagic GmbH, Stuttgart, Germany) for data } \\
\text { conversion, model processing, registration, and } \\
\text { 3D analysis. }\end{array}$ \\
\hline $\begin{array}{l}\text { Ghoneima et al., } \\
\text { Orthod Craniofac } \\
\text { Res (2017) }\end{array}$ & $\begin{array}{l}\text { 1. Landmark-based Registration } \\
\text { 2. Surface-based Registration } \\
\text { (iterative closest point) } \\
\text { 3. Voxel-based Registration } \\
\text { (iterative best match of grey } \\
\text { scale intensities) }\end{array}$ & $\begin{array}{l}\text { 1. Seven homologous points on the } \\
\text { frontal and zygomatic bones } \\
\text { 2. Anterior cranial base surface } \\
\text { 3. Anterior cranial base (anterior wall of } \\
\text { frontal sinus anteriorly, the anterior } \\
\text { clinoid process posteriorly, the superior } \\
\text { wall of ethmoid sinus superiorly and } \\
\text { the inferior floor of sphenoid sinus } \\
\text { inferiorly) }\end{array}$ & NA & $\begin{array}{l}\text { CBCT: iCAT 3D } \\
\text { imaging System } \\
\text { (Imaging Sciences } \\
\text { International, Hatfield, } \\
\text { PA, USA) }\end{array}$ & $\begin{array}{l}\text { Tube voltage: } 120 \mathrm{kV} \text {; Tube } \\
\text { current: } 20 \mathrm{~mA} ; \mathrm{FOV}: 17 \times 23 \mathrm{~cm} ; \\
\text { Voxel size: } 0.3 \mathrm{~mm} 3 \text {; Exposure: } \\
8.9 \mathrm{~s}\end{array}$ & $\begin{array}{l}\text { 1 and 3: Dolphin software version } 11.8 \text { Premium } \\
\text { (Dolphin Imaging and Management Solutions, } \\
\text { Chatsworth, CA, USA) for the registration. } \\
\text { 2: 3dMD Vultus soffware (3dMD, Atlanta, GA, } \\
\text { USA) for the registration. }\end{array}$ \\
\hline
\end{tabular}


3 Table 3 Continued

\begin{tabular}{|c|c|c|c|c|c|c|}
\hline Study & Superimposition methods & References & \begin{tabular}{|l|} 
No of \\
Operators
\end{tabular} & Machines & Acquisition parameters & Software \\
\hline $\begin{array}{l}\text { Häner et al., } \\
\text { Orthod Craniofac } \\
\text { Res (2019) }\end{array}$ & $\begin{array}{l}\text { Voxel-based Registration } \\
\text { (iterative best match of grey } \\
\text { scale intensities) }\end{array}$ & $\begin{array}{l}\text { Anterior cranial base (from the middle } \\
\text { of the sella turcica to the posterior wall } \\
\text { of the sinus frontalis. The vertical } \\
\text { height of the area is about } 3.5 \mathrm{~cm} \text {. The } \\
\text { lower vertical limit was set } 2-4 \mathrm{~mm} \\
\text { below the lowest point of the sella } \\
\text { turcica. The lateral limits extend till the } \\
\text { lateral walls of the cranium) }\end{array}$ & 2 & $\begin{array}{l}\text { CBCT: KaVo3D eXam } \\
\text { (Hatfield, PA 19440, } \\
\text { USA) }\end{array}$ & $\begin{array}{l}\text { Tube voltage: } 120 \mathrm{kV} \text {; Tube } \\
\text { current: } 5 \mathrm{~mA} \text {; FOV: } 170 \text { height } \\
\mathrm{mm} \times 232 \mathrm{~mm} \text {; Voxel size: } 0.4 \\
\text { mm3; Scan time: } 8.9 \mathrm{~s} \text {; } \\
\text { Exposure: } 3.7 \mathrm{~s}\end{array}$ & $\begin{array}{l}\text { Dolphin 3D software (version 2.1.6079.17633) for } \\
\text { surface model creation and the voxel-based } \\
\text { registration. } \\
\text { Viewbox } 4 \text { software (version 4.1.0.1 BETA 64) for } \\
\text { surface model processing and analysis. }\end{array}$ \\
\hline $\begin{array}{l}\text { Koerich et al., } \\
\text { Int J Oral Maxillofac } \\
\text { Surg (2016) }\end{array}$ & $\begin{array}{l}\text { Voxel-based Registration } \\
\text { (iterative best match of grey } \\
\text { scale intensities) }\end{array}$ & $\begin{array}{l}\text { Maxilla (zygomatic process and } \\
\text { palate) and Mandible (Symphysis, } \\
\text { corpus and part of ramus) }\end{array}$ & 2 & $\begin{array}{l}\text { 1. CBCT: Kodak } \\
\text { Carestream } 9300 \\
\text { (Carestream Health } \\
\text { Inc., Rochester, NY, } \\
\text { USA) } \\
\text { 2. CBCT: i-CAT } \\
\text { scanner (Imaging } \\
\text { Sciences International } \\
\text { LLC, Hatfield, PA, } \\
\text { USA) }\end{array}$ & $\begin{array}{l}\text { 1. Tube voltage: } 85 \mathrm{kVp} \text {; Tube } \\
\text { current: } 4 \mathrm{~mA} \text {; FOV: } 13.5 \times 17 \mathrm{~cm} \text {; } \\
\text { Voxel size: } 0.3 \mathrm{~mm} 3 \text {; Exposure: } \\
11.3 \mathrm{~s} \\
\text { 2. Tube voltage: } 120 \mathrm{kVp} \text {; Tube } \\
\text { current: } 8 \mathrm{~mA} \text {; FOV: } 16 \times 13 \mathrm{~cm} ; \\
\text { Voxel size: } 0.25 \mathrm{~mm} 3 ; \text { Exposure: } \\
27 \mathrm{~s}\end{array}$ & $\begin{array}{l}\text { OnDemand 3D software v1.0.10.5261 } \\
\text { (Cybermed, Seoul, Korea) for image processing, } \\
\text { segmentation and registration. } \\
\text { VAM software (Canfield Scientific, Fairfield, NJ, } \\
\text { USA) for analysis. }\end{array}$ \\
\hline $\begin{array}{l}\text { Koerich et al., } \\
\text { Angle Orthod } \\
(2017)\end{array}$ & $\begin{array}{l}\text { Voxel-based Registration } \\
\text { (iterative best match of grey } \\
\text { scale intensities) }\end{array}$ & $\begin{array}{l}\text { Lower mandibular border below to } \\
\text { tooth apices, extending from the } \\
\text { middle of the symphysis to the distal of } \\
\text { the first molars }\end{array}$ & 2 & $\begin{array}{l}\text { CBCT: i-CAT scanner } \\
\text { (Imaging Sciences } \\
\text { International, Hatfield, } \\
\text { PA) }\end{array}$ & $\begin{array}{l}\text { Tube voltage: } 120 \mathrm{kVp} \text {; Tube } \\
\text { current: } 8 \mathrm{~mA} \text {; Voxel size: } 0.3 \\
\mathrm{~mm} 3 \text {; Exposure: } 40 \mathrm{~s}\end{array}$ & $\begin{array}{l}\text { OnDemand 3D software v1.0.10.5261 } \\
\text { (Cybermed, Seoul, Korea) for image processing, } \\
\text { segmentation and registration. } \\
\text { VAM software (Canfield Scientific, Fairfield, NJ, } \\
\text { USA) for analysis. }\end{array}$ \\
\hline $\begin{array}{l}\text { Lemieux et al., } \\
\text { Am J Orthod } \\
\text { Dentofacial Orthop } \\
\text { (2014) }\end{array}$ & $\begin{array}{l}\text { Landmark-derived plane } \\
\text { Registration }\end{array}$ & $\begin{array}{l}\text { Maxillary superimposition plane } \\
\text { formed by nasion, bilateral infraorbital } \\
\text { foramina and incisive foramen }\end{array}$ & 1 & $\begin{array}{l}\text { CBCT: NewTom 3G } \\
\text { volumetric scanner } \\
\text { (Aperio, Verona, Italy) }\end{array}$ & $\begin{array}{l}\text { Tube voltage: } 110 \mathrm{kV} \text {; Tube } \\
\text { current: } 6.19 \text { mAs; Voxel size: } \\
0.25 \mathrm{~mm} 3 \text {; Thickness Aluminium } \\
\text { filtre: } 8 \mathrm{~mm}\end{array}$ & $\begin{array}{l}\text { MATLAB software (R2008a; MathWorks, Natick, } \\
\text { Mass) for landmarks-based registration. } \\
\text { Avizo software (version 6.0; Visualization } \\
\text { Sciences Group, Burlington, Mass) for landmark } \\
\text { location and analysis. }\end{array}$ \\
\hline $\begin{array}{l}\text { Nada et al., } \\
\text { PLoS One (2011) }\end{array}$ & $\begin{array}{l}\text { Voxel-based Registration } \\
\text { (iterative best match of the grey } \\
\text { scale intensities) }\end{array}$ & $\begin{array}{l}\text { 1. Anterior cranial base (AC) } \\
\text { 2. Left zygomatic arch (ZL) }\end{array}$ & 2 & $\begin{array}{l}\text { CBCT: i-CAT 3D } \\
\text { Imaging System } \\
\text { (Imaging Sciences } \\
\text { International INC, } \\
\text { Hatfield, PA, USA) }\end{array}$ & $\begin{array}{l}\text { FOV: } 22 \times 16 \mathrm{~cm} \text {; Voxel size: } 0.4 \\
\text { mm3 }\end{array}$ & $\begin{array}{l}\text { Maxilim software (Medicim, Mechelen, Belgium) } \\
\text { for } 3 \mathrm{D} \text { model construction, superimposition and } \\
\text { analysis }\end{array}$ \\
\hline $\begin{array}{l}\text { Nguyen et al., } \\
\text { Am J Orthod } \\
\text { Dentofacial Orthop } \\
\text { (2017) }\end{array}$ & $\begin{array}{l}\text { Voxel-based Registration } \\
\text { (iterative best match of grey } \\
\text { scale intensities) }\end{array}$ & $\begin{array}{l}\text { 1. Bony plates and mini-screws in the } \\
\text { mandibular anterior area } \\
2 \text {. Chin (anterior surface of the chin } \\
\text { bounded vertically from pogonion to B- } \\
\text { point and laterally at the distal-incisal } \\
\text { point of the right and left lateral } \\
\text { incisors) + Symphysis (internal cortical } \\
\text { bone of the mandibular symphysis at } \\
\text { the lateral limit of its lingual surface } \\
\text { and from its inferior border to the level } \\
\text { of the center of both mental foramina) }\end{array}$ & 2 & $\begin{array}{l}\text { CBCT: i-CAT machine } \\
\text { (Imaging Sciences } \\
\text { International, Hatfield, } \\
\text { PA) } \\
\text { CBCT: NewTom 3G } \\
\text { (AFP Imaging, } \\
\text { Elmsford, NY) }\end{array}$ & $\begin{array}{l}\text { Tube voltage: } 12 \mathrm{kV}(\mathrm{p}) ; \text { Tube } \\
\text { current: } 5 \mathrm{~mA} \text {; Voxel size: } 0.3 \\
\mathrm{~mm} 3 \text {; Exposure: } 20-25 \mathrm{~s}\end{array}$ & $\begin{array}{l}\text { ITK-SNAP software (version 3.6; open-source } \\
\text { software, http://www.itksnap.org) for 3D } \\
\text { mandibular models creation. } \\
\text { Slicer CMF software (version 3.1; } \\
\text { http://www.slicer.org) to create surface models } \\
\text { and registration. }\end{array}$ \\
\hline
\end{tabular}




\section{Table 3 Continued}

\begin{tabular}{|c|c|c|c|c|c|c|}
\hline Study & Superimposition methods & References & $\begin{array}{l}\text { No of } \\
\text { Operators }\end{array}$ & Machines & Acquisition parameters & Software \\
\hline $\begin{array}{l}\text { Ruellas et al., } \\
\text { Am J Orthod } \\
\text { Dentofacial } \\
\text { Orthop (2016a) }\end{array}$ & $\begin{array}{l}\text { Voxel-based Registration (iterative } \\
\text { best match of the grey scale } \\
\text { intensities) }\end{array}$ & $\begin{array}{l}\text { 1. Maxillary region (maxillary bone } \\
\text { clipped inferiorly at the dentoalveolar } \\
\text { processes, superiorly at the plane } \\
\text { passing through the right and left } \\
\text { orbitale points, laterally at the } \\
\text { zygomatic processes through the } \\
\text { orbitale point, and posteriorly till the } \\
\text { distal surface of the second molars) } \\
\text { 2. Palate and Infrazygomatic region } \\
\text { (same as above cropped posteriorly } \\
\text { distal aspects to the first molars and } \\
\text { anteriorly at the canines) }\end{array}$ & 2 & $\begin{array}{l}\text { CBCT: i-Cat machine } \\
\text { (Imaging Sciences } \\
\text { International, Hatfield, } \\
\text { PA) }\end{array}$ & $\begin{array}{l}\text { FOV: } 16 \times 22 \mathrm{~cm} \text {; Voxel size: } 0.4 \\
\text { mm3 }\end{array}$ & $\begin{array}{l}\text { Slicer software (version 4.3.1; } \\
\text { http://www.slicer.org) for the registration } \\
\text { ITK-SNAP software (http://www.itksnap.org) for } \\
\text { data conversion and 3D models construction. } \\
\text { VECTRA Anaylsis Module software (version } \\
\text { 3.7.6; Canfield Scientific, Fairfield, NJ) for } \\
\text { landmark generation and analysis. }\end{array}$ \\
\hline $\begin{array}{l}\text { Ruellas et al., } \\
\text { PLoS One } \\
\text { (2016b) }\end{array}$ & $\begin{array}{l}\text { Voxel-based Registration (iterative } \\
\text { best match of grey scale } \\
\text { intensities) }\end{array}$ & $\begin{array}{l}\text { 1. Maxillary region (maxillary bone } \\
\text { clipped inferiorly at the dentoalveolar } \\
\text { processes, superiorly at the plane } \\
\text { passing through the right and left } \\
\text { orbitale points, laterally at the } \\
\text { zygomatic processes through the } \\
\text { orbitale point, and posteriorly at a } \\
\text { plane passing through the distal } \\
\text { surface of the second molars) } \\
\text { 2. Palate \& infrazygomatic region } \\
\text { (same as above cropped posteriorly at } \\
\text { the plane passing through the distal } \\
\text { aspects of the first molars and } \\
\text { anteriorly at the canines) }\end{array}$ & NA & CBCT: NA & $\begin{array}{l}\text { FOV: } 16 \times 22 \mathrm{~cm} \text {; Voxel size: } 0.4 \\
\text { mm3 }\end{array}$ & $\begin{array}{l}\text { Slicer software (v4.4; http://www.slicer.org) for } \\
\text { data analysis and registration. } \\
\text { ITK-SNAP software (http://www.itkspnap.org) for } \\
\text { the segmentation. }\end{array}$ \\
\hline $\begin{array}{l}\text { Weissheimer et } \\
\text { al., } \\
\text { Int J Oral } \\
\text { Maxillofac Surg } \\
(2015)\end{array}$ & $\begin{array}{l}\text { Voxel-based Registration (iterative } \\
\text { best match of grey scale } \\
\text { intensities) }\end{array}$ & Anterior cranial base & NA & $\begin{array}{l}\text { CBCT: iCat (Imaging } \\
\text { Sciences } \\
\text { International, Hatfield, } \\
\text { PA) }\end{array}$ & $\begin{array}{l}\text { Tube voltage: } 120 \mathrm{kVp} ; 8 \mathrm{~mA} \text {; } \\
\text { FOV: large; Voxel size: } 0.25 \\
\text { mm3; Exposure: } 40 \mathrm{~s}\end{array}$ & $\begin{array}{l}\text { OnDemand 3D software v1.0.10.5261 } \\
\text { (Cybermed, Seoul, Korea) for the registration. }\end{array}$ \\
\hline
\end{tabular}


Table 4 (on next page) 
1 Table 4 Results of the included studies.

\begin{tabular}{|c|c|c|c|c|}
\hline Study & Main Outcomes & $\begin{array}{l}\text { Secondary } \\
\text { Outcomes }\end{array}$ & Main Results & Secondary Results \\
\hline $\begin{array}{l}\text { Almukhtar et al., } \\
\text { PLoS One (2014) }\end{array}$ & $\begin{array}{l}\text { Mean absolute distance of surface models in unchanged areas (anterior cranial base for } \\
\text { hard tissue and forehead for soft tissue models): } 1 \text {. VBR hard; } 2 \text {. VBR soft; } 3 \text {. SBR hard; } \\
\text { 4. SBR soft }\end{array}$ & $\begin{array}{l}\text { Correlation between } \\
\text { VBR and SBR } \\
\text { results on hard and } \\
\text { soft tissues }\end{array}$ & $\begin{array}{l}\text { Mean absolute distances }(\mathrm{mm}): 1.0 .050 \pm \\
0.206 ; 2.0 .294 \pm 0.334 ; 3.0 .047 \pm 0.259 ; 4 \\
0.230 \pm 0.561 \\
\text { VBR hard }- \text { SBR hard }(p=0.392) \\
\text { VBR soft - SBR soft }(p=0.243)\end{array}$ & $\begin{array}{l}\text { VBR hard - SBR hard: } r= \\
0.886 \\
\text { VBR soft - SBR soft: } r= \\
0.126\end{array}$ \\
\hline $\begin{array}{l}\text { Bazina et al., } \\
\text { Am J Orthod Dentofacial } \\
\text { Orthop (2018) }\end{array}$ & $\begin{array}{l}\text { 1. Reproducibility of the Dolphin technique } \\
\text { 2. Agreement with the ITK-Snap+3D Slicer assessed through the mean differences at } 7 \\
\text { areas: a. Nasion area; b. A-point area; c. Right zygomatic area; d. Left zygomatic area; } \\
\text { e. Right gonial angle; f. B-point area; g. Left gonial angle }\end{array}$ & NA & $\begin{array}{l}\text { 1. } I C C=0.964(0.941-0.978) \\
\text { 2. Mean differences }(\mathrm{mm})=\mathrm{a} .0 .099 \pm 0.072 ; \mathrm{b} . \\
0.188 \pm 0.110 ; \mathrm{c} .0 .113 \pm 0.086 ; \text { d. } 0.092 \pm \\
0.057 ; \text { e. } 0.210 \pm 0.136 ; \text { f. } 0.189 \pm 0.101 ; \mathrm{g} \\
0.169 \pm 0.082\end{array}$ & $\mathrm{NA}$ \\
\hline $\begin{array}{l}\text { Cevidanes et al., } \\
\text { Dentomaxillofaci Radiol (2005) }\end{array}$ & $\begin{array}{l}\text { Inter-operator agreement on surface distance measurements of 3D models at } 3 \\
\text { mandibular regions: } 1 \text {. Anterior mandibular ramus, 2. Posterior mandibular ramus, } 3 . \\
\text { Condyles }\end{array}$ & NA & $\begin{array}{l}\text { Surface distances }(\mathrm{mm}): 1.0 .25 \pm 0.11 ; 2.0 .13 \\
\pm 0.05 ; 3.0 .09 \pm 0.05\end{array}$ & $\mathrm{NA}$ \\
\hline $\begin{array}{l}\text { Cevidanes et al., } \\
\text { Am J Orthod Dentofacial } \\
\text { Orthop (2009) }\end{array}$ & $\begin{array}{l}\text { Inter-operator agreement on surface distance measurements of 3D models at } 9 \text { regions: } \\
\text { 1. Zygomatic process, } 2 \text {. Anterior maxilla, 3. Chin, } 4 \text {. Right anterior condyle, } 5 \text {. Right } \\
\text { posterior condyle, } 6 \text {. Left anterior condyle, } 7 \text {. Left posterior condyle, } 8 \text {. Mandibular } \\
\text { inferior border, } 9 \text { Soft-tissue upper lip }\end{array}$ & $\mathrm{NA}$ & $\begin{array}{l}\text { Surface distances }(\mathrm{mm}): 1.0 .1-0.4 ; 2.0 .2- \\
0.5 ; 3.0 .1-0.4 ; 4.0 .0-0.3 ; 5.0 .1-0.4 ; 6.0 .0- \\
0.3 ; 7.0 .0-0.4 ; 8.0 .2-0.4 ; 9.0 .3-0.5\end{array}$ & NA \\
\hline $\begin{array}{l}\text { Gkantidis et al., } \\
\text { PLoS One (2015) }\end{array}$ & $\begin{array}{l}\text { A. Trueness (overall deviation of surface models at unchanged areas: AC +F) } \\
\text { B. Intra-operator agreement (on measured structural changes at four corresponding } \\
\text { landmarks) of different superimposition techniques: 1. 3P; } 2.1 Z ; 3 \text {. BZ; 4. AC; } 5 . \text { AC+F } \\
\text { C. Inter-operator agreement assessed as described above }\end{array}$ & $\mathrm{NA}$ & $\begin{array}{l}\text { A. Trueness (median values of the } 3 \text { operators } \\
\text { in } m m): 1.0 .79-1.01 ; 2.1 .42-1.76 ; 3.0 .31- \\
0.57 ; 4.0 .35-0.52 ; 5.0 .07-0.11(p=0.0002) \\
\text { B. } p=0.854 \\
\text { C. } p=0.661 ; r>0.91 \text { for all except } 3 P\end{array}$ & $\mathrm{NA}$ \\
\hline $\begin{array}{l}\text { Ghoneima et al., } \\
\text { Orthod Craniofac Res (2017) }\end{array}$ & $\begin{array}{l}\text { A. Reproducibility of each superimposition technique } \\
\text { B. Mean absolute distance between manually located landmarks on superimposed } \\
\text { duplicated scans (ACP, Ba-x, Ba-y, PNS-y, B point-x, Me-x, U1-x, L1-x) }\end{array}$ & NA & $\begin{array}{l}\text { Surface-based and Voxel-based } \\
\text { superimposition methods using the anterior } \\
\text { cranial base as reference seem to be } \\
\text { reproducible whereas Landmarks-based } \\
\text { superimposition is less reproducible. }\end{array}$ & NA \\
\hline $\begin{array}{l}\text { Häner et al., } \\
\text { Orthod Craniofac Res (2019) }\end{array}$ & $\begin{array}{l}\text { 1. Trueness of the voxel-based superimposition assessed through visual inspection of } \\
\text { corresponding reference structures } \\
\text { 2. Intra-operator reproducibility assessed through the mean absolute distance (MAD) of } \\
\text { the repeatedly superimposed T0 surface models measured in the following areas: N- } \\
\text { point, A-point, Pogonion, Right and Left zygomatic arch, Right and left gonial angle } \\
\text { 3. Inter-operator reproducibility assessed as described above }\end{array}$ & $\begin{array}{l}\text { Segmentation effect } \\
\text { (manual and } \\
\text { automatic) assessed } \\
\text { as the intra- and } \\
\text { interoperator } \\
\text { reproducibility }\end{array}$ & $\begin{array}{l}\text { 1. In all cases, visual inspection of the } \\
\text { superimposed T0-T1 volumes presented } \\
\text { adequate overlap } \\
\text { 2. MAD }(0.06-0.16 \mathrm{~mm}) \text {. In very few cases, it } \\
\text { exceeded } 0.5 \mathrm{~mm} \text { and never } 1 \mathrm{~mm} \\
\text { 3. MAD }(0.15-0.24 \mathrm{~mm}) \text {. In few cases, it } \\
\text { exceeded } 0.5 \mathrm{~mm} \text { and never } 1.5 \mathrm{~mm}\end{array}$ & $\begin{array}{l}\text { The median segmentation } \\
\text { error ranged from } 0.05-0.12 \\
\mathrm{~mm} \text {. The biggest } \\
\text { segmentation error was } \\
\text { found at A-point }(0.3 \mathrm{~mm})\end{array}$ \\
\hline $\begin{array}{l}\text { Koerich et al., } \\
\text { Int J Oral Maxillofac Surg } \\
(2016)\end{array}$ & $\begin{array}{l}\text { A. Intra-operator agreement on surface distance measurements (RMSD) of serial 3D } \\
\text { models at } 2 \text { regions of the maxilla and } 3 \text { regions of the mandible (average difference) } \\
\text { B. Inter-operator agreement assessed as described above }\end{array}$ & NA & \begin{tabular}{|l|} 
A.1 Intra-operator agreement $(\mathrm{mm}):$ NA \\
A.2 Intra-operator agreement $(\mathrm{mm})$. Maxilla: \\
$0.183-0.184$, Mandible: $-0.005-0.001$ \\
B.1 Inter-operator agreement $(\mathrm{mm})$. Maxilla: \\
$0.087-0.098$, Mandible: $0.183-0.184$ \\
B.2 Inter-operator agreement $(\mathrm{mm})$. Maxilla: \\
$0.072-0.092$, Mandible: $0.087-0.105$
\end{tabular} & NA \\
\hline
\end{tabular}


3 Table 4 Continued

\begin{tabular}{|c|c|c|c|c|}
\hline Study & Main Outcomes & Secondary Outcomes & Main Results & Secondary Results \\
\hline $\begin{array}{l}\text { Koerich et al., } \\
\text { Angle Orthod (2017) }\end{array}$ & $\begin{array}{l}\text { Inter-operator agreement on surface distance measurements (RMSD) at } 5 \\
\text { mandibular regions: } 1 \text {. Right mandible, } 2 \text {. Chin, } 3 \text {. Left mandible, } 4 \text {. Right } \\
\text { ramus, and } 5 \text {. Left ramus, located at the outer surface of the mandible }\end{array}$ & NA & $\begin{array}{l}\text { Surface distances }(\mathrm{mm}): 1 \\
0.11 \pm 0.12 ; 2.0 .14 \pm 0.1 ; 3 \\
0.11 \pm 0.16 ; 4.0 .33 \pm 0.29 ; 5 \\
0.36 \pm 0.33\end{array}$ & \\
\hline $\begin{array}{l}\text { Lemieux et al., } \\
\text { Am J Orthod Dentofacial } \\
\text { Orthop (2014) }\end{array}$ & $\begin{array}{l}\text { Amount of expansion at the levels of the first premolars (from tip to tip of } \\
\text { each buccal cusp) and the first molars (from tip to tip of each mesiobuccal } \\
\text { cusp) on 1. plaster models and 2. 3D plane superimposition }\end{array}$ & $\begin{array}{l}\text { Landmark identification } \\
\text { reproducibility through ICC }\end{array}$ & $\begin{array}{l}\text { Mean distances measured } \\
\text { between premolars }(\mathrm{mm}): 1 \\
2.97 \pm 2.12 ; 2.3 .06 \pm 1.97 \\
\text { Mean distances measured } \\
\text { between molars }(\mathrm{mm}): 1.4 .18 \\
\pm 1.62 ; 2.4 .28 \pm 1.61\end{array}$ & $\begin{array}{l}\mathrm{ICC}>0.924,0.992,0.973 \text { in the } \mathrm{x}, \mathrm{y}, \text { and } \mathrm{z} \\
\text { axes respectively }\end{array}$ \\
\hline $\begin{array}{l}\text { Nada et al., } \\
\text { PLoS One (2011) }\end{array}$ & $\begin{array}{l}\text { Mean absolute distance of surface models on the following stable areas: a. } \\
\text { anterior cranial base (CB); b. forehead (FH); c. left zygomatic arch (ZL); d. } \\
\text { right zygomatic arch (ZR) }\end{array}$ & $\begin{array}{l}\text { A. Mean differences between } \\
\text { the two superimposition } \\
\text { techniques } \\
\text { B. Mean differences between } \\
\text { repeated AC superimposition } \\
\text { measurements } \\
\text { C. Mean differences between } \\
\text { repeated LZ superimposition } \\
\text { measurements }\end{array}$ & $\begin{array}{l}\text { Mean distances measured } \\
\text { between the models }(\mathrm{mm}): 1 \text {. } \\
0.20-0.37 \text { (SD: } 0.08-0.16) \text {; } \\
2.0 .20-0.45 \text { (SD: } 0.09- \\
0.27 \text { ) }\end{array}$ & $\begin{array}{l}\text { A. Mean differences }(\mathrm{mm}): \text { a. } 0.12 \pm 0.19 ; \text { b. } \\
0.19 \pm 0.12 \text {; c. } 0.15 \pm 0.18 \text {; d. }-0.17 \pm 0.13 \\
\text { B. Mean differences }(\mathrm{mm}) \text { : a. } 0.02 \pm 0.09 ; \text { b. } \\
0.01 \pm 0.07 \text {; c. }-0.07 \pm 0.12 \text {; d. } 0.04 \pm 0.09 \\
\text { C. Mean differences }(\mathrm{mm}): \text { a. }-0.07 \pm 0.25 \text {; b. } \\
0.04 \pm 0.24 ; \text { c. } 0.14 \pm 0.10 \text {; d. } 0.04 \pm 0.09\end{array}$ \\
\hline $\begin{array}{l}\text { Nguyen et al., } \\
\text { Am J Orthod Dentofacial } \\
\text { Orthop (2017) }\end{array}$ & $\begin{array}{l}\text { 1. Absolute mean surface distance of the registered models on plates and } \\
\text { screws, calculated at } 3 \text { regions: a. Chin, b. Symphysis, c. Lower contour of } \\
\text { the third molar crypt } \\
\text { 2. Reproducibility of the combined chin+symphysis regions measured } \\
\text { through ICC and mean absolute distances of the entire surface of T2 } \\
\text { registered mandibular models by two operators }\end{array}$ & NA & $\begin{array}{l}\text { 1. Absolute mean surface } \\
\text { distance }(\mathrm{mm}): \text { a. } 0.37 \pm 0.16 \text {; } \\
\text { b. } 0.40 \pm 0.14 ; \mathrm{c} .1 .94 \pm 0.06 \\
\text { 2. ICC }=0.998(95 \% \mathrm{Cl}: \\
0.995-1.000)\end{array}$ & NA \\
\hline $\begin{array}{l}\text { Ruellas et al., } \\
\text { Am J Orthod Dentofacial } \\
\text { Orthop (2016a) }\end{array}$ & $\begin{array}{l}\text { Differences between corresponding landmark distances from T0-T1 } \\
\text { measured through the two superimpositions }\end{array}$ & $\begin{array}{l}\text { A. Precision and B. } \\
\text { reproducibility of each } \\
\text { technique measured as } \\
\text { differences in Euclidean } \\
\text { distances of corresponding } \\
\text { landmarks }\end{array}$ & $\begin{array}{l}\text { Mean differences }(\mathrm{mm}): 0.35 \\
-0.39 \text { (SD: } 0.23-0.24)\end{array}$ & $\begin{array}{l}\text { A. Mean differences }(\mathrm{mm}): 0.36-0.42 \text { (SD: } \\
0.21-0.24 \text { ) } \\
\text { B. Mean differences }(\mathrm{mm}): 0.31-0.44 \text { (SD: } \\
0.16-0.28 \text { ) }\end{array}$ \\
\hline $\begin{array}{l}\text { Ruellas et al., } \\
\text { PLoS One (2016b) }\end{array}$ & $\begin{array}{l}\text { Difference of corresponding landmark distances between T0-T1 calculated } \\
\text { through superimposition on } 3 \text { different reference regions, compared to direct } \\
\text { measurements of landmark movements from a point considered stable }\end{array}$ & NA & $\begin{array}{l}\text { NA (Mean values provided } \\
\text { were outside of the Limits of } \\
\text { Agreement range) }\end{array}$ & NA \\
\hline $\begin{array}{l}\text { Weissheimer et al., } \\
\text { Int J Oral Maxillofac Surg } \\
\text { (2015) }\end{array}$ & $\begin{array}{l}\text { Visual inspection of the superimposition technique and trueness assessment } \\
\text { through visualisation of } 3 \mathrm{D} \text { colour maps }\end{array}$ & $\begin{array}{l}\text { Visual inspection of the } \\
\text { effectiveness of the technique } \\
\text { through superimposition of } \\
\text { reoriented identical models }\end{array}$ & $\begin{array}{l}\text { Highest distance between } \\
\text { corresponding anterior cranial } \\
\text { base references is less than } \\
0.5 \mathrm{~mm} \text { for growing and non- } \\
\text { growing patients }\end{array}$ & $\begin{array}{l}\text { Highest distance between identical, reoriented } \\
\text { anterior cranial bases was less than } 0.25 \mathrm{~mm}\end{array}$ \\
\hline
\end{tabular}


Table 5 (on next page) 
1 Table 5 Conclusions and limitations of the included studies.

\begin{tabular}{|c|c|c|}
\hline Study & Conclusions & Limitations \\
\hline $\begin{array}{l}\text { Almukhtar et al., } \\
\text { PLoS One (2014) }\end{array}$ & $\begin{array}{l}\text { No differences between Voxel-based registration and } \\
\text { Surface-based registration. } \\
\text { High inconsistency between VBR and SBR regarding soft } \\
\text { tissues. }\end{array}$ & $\begin{array}{l}\text { I. No method error } \\
\text { II. In SBR, hard and soft tissues were superimposed separately whereas in VBR, hard and soft tissues were all superimposed at once }\end{array}$ \\
\hline $\begin{array}{l}\text { Bazina et al., } \\
\text { Am J Orthod Dentofacial } \\
\text { Orthop (2018) }\end{array}$ & $\begin{array}{l}\text { The Dolphin 3D software seems to work properly for voxel- } \\
\text { based registration in the anterior cranial base. }\end{array}$ & $\begin{array}{l}\text { I. The original change that occurred over time is not reported. } \\
\text { II. ICC values were calculated from only } 10 \text { patients and for the average of all measurements. } \\
\text { III. There was no assessment of the reproducibility of each individual measurement/case. } \\
\text { IV. The type of ICC used is not reported. }\end{array}$ \\
\hline $\begin{array}{l}\text { Cevidanes et al., } \\
\text { Dentomaxillofac Radiol } \\
\text { (2005) }\end{array}$ & $\begin{array}{l}\text { The technique shows acceptable reproducibility in the } \\
\text { assessment of relatively unaltered structures. }\end{array}$ & $\begin{array}{l}\text { I. There were relatively large interobserver errors compared to the detected changes. } \\
\text { II. The actual measured changes were originally small }(<0.8 \mathrm{~mm}) \text {. }\end{array}$ \\
\hline $\begin{array}{l}\text { Cevidanes et al., } \\
\text { Am J Orthod Dentofacial } \\
\text { Orthop (2009) }\end{array}$ & $\begin{array}{l}\text { The technique provides reproducible 3D assessment of } \\
\text { growing patients. }\end{array}$ & I. Small sample size that did not allow statistical comparisons \\
\hline $\begin{array}{l}\text { Gkantidis et al., } \\
\text { PLoS One (2015 }\end{array}$ & $\begin{array}{l}\text { Superimposition of 3D surface models created from voxel } \\
\text { data can provide accurate, precise and reproducible results } \\
\text { when appropriate references are used. } \\
\text { Superimposition on BZ could be an alternative to AC. }\end{array}$ & $\begin{array}{l}\text { I. CT data were used } \\
\text { II. No assessment of individual measurements regarding reproducibility }\end{array}$ \\
\hline $\begin{array}{l}\text { Ghoneima et al., } \\
\text { Orthod Craniofac Res } \\
\text { (2017) }\end{array}$ & $\begin{array}{l}\text { Surface-based and Voxel-based superimposition methods } \\
\text { using the anterior cranial base as reference seem to be } \\
\text { reproducible whereas Landmarks-based superimposition is } \\
\text { less reproducible. }\end{array}$ & $\begin{array}{l}\text { I. The original change that occurred over time is not reported. } \\
\text { II. ICC values were calculated from only } 10 \text { patients and for the average of all measurements. There was no assessment of the } \\
\text { reproducibility of each individual measurement/case. } \\
\text { III. The type of ICC used is not reported. } \\
\text { IV. The time span between serial images is not reported. }\end{array}$ \\
\hline $\begin{array}{l}\text { Häner et al., } \\
\text { Orthod Craniofac Res } \\
\text { (2019) }\end{array}$ & $\begin{array}{l}\text { The Dolphin voxel-based superimposition technique } \\
\text { exhibited adequate performance in growing patients, in } \\
\text { terms of efficiency, cranial base matching, and } \\
\text { reproducibility. } \\
\text { The segmentation error was also acceptable in most cases. }\end{array}$ & $\begin{array}{l}\text { I. The trueness of the voxel-based superimposition was assessed through visual inspection of corresponding reference structures in } \\
\text { 2D. } \\
\text { II. The original changes between T0 and T1 were relatively limited, though no relation was evident between the amount of change } \\
\text { and the error of the process. }\end{array}$ \\
\hline $\begin{array}{l}\text { Koerich et al., } \\
\text { Int J Oral Maxillofac Surg } \\
(2016)\end{array}$ & $\begin{array}{l}\text { The technique shows high precision and reproducibility } \\
\text { tough these were assessed in relatively unaltered structures. } \\
\text { Furthermore, differences between reoriented dry skulls were } \\
\text { larger than expected. }\end{array}$ & $\begin{array}{l}\text { I. The changes of the structures that were evaluated were quite small }(<0.3 \mathrm{~mm}) \text {. } \\
\text { II. Differences between the serial images of reoriented dry skulls were higher than those of actual serial scans. } \\
\text { III. Samples from different machines were tested }\end{array}$ \\
\hline $\begin{array}{l}\text { Koerich et al., } \\
\text { Angle Orthod (2017) }\end{array}$ & $\begin{array}{l}\text { The technique shows moderate reproducibility in the } \\
\text { assessment of relatively unaltered structures. }\end{array}$ & $\begin{array}{l}\text { I. Relatively large interobserver errors compared to the detected changes. } \\
\text { II. The changes measured were small }(<0.9 \mathrm{~mm})\end{array}$ \\
\hline $\begin{array}{l}\text { Lemieux et al., } \\
\text { Am J Orthod Dentofacial } \\
\text { Orthop (2014) }\end{array}$ & $\begin{array}{l}\text { The landmark-derived maxillary plane cannot be assessed } \\
\text { through the present methodology. }\end{array}$ & $\begin{array}{l}\text { I. The main outcome is not suitable for the assessment of the superimposition result because it remains unaffected by the } \\
\text { superimposition itself. } \\
\text { II. The landmark identification error is not thoroughly assessed for individual cases. }\end{array}$ \\
\hline $\begin{array}{l}\text { Nada et al., } \\
\text { PLoS One (2011) }\end{array}$ & $\begin{array}{l}\text { This technique might show good trueness and reproducibility. } \\
\text { Registration on the left zygomatic arch seems to be less } \\
\text { accurate, but it might still be clinically acceptable and } \\
\text { reproducible. }\end{array}$ & $\begin{array}{l}\text { I. Only structures considered stable were evaluated and thus the measured changes were small. } \\
\text { II. Only mean values are provided and analysed and thus possible larger individual differences are ignored. }\end{array}$ \\
\hline
\end{tabular}

2 
3 Table 5 Continued

\begin{tabular}{|c|c|c|}
\hline Study & Conclusions & Limitations \\
\hline $\begin{array}{l}\text { Nguyen et al., } \\
\text { Am J Orthod Dentofacial Orthop } \\
(2017)\end{array}$ & $\begin{array}{l}\text { The chin and the symphysis region might be an } \\
\text { anatomically stable reference area for mandibular } \\
\text { superimpositions, whereas the third molar region } \\
\text { displayed a higher instability. } \\
\text { The chin+symphysis area seems to provide reproducible } \\
\text { results. }\end{array}$ & $\begin{array}{l}\text { I. The bone plates and screws were confirmed to be immobile clinically, but their stability in space was not tested (e.g. through best } \\
\text { fit registration). } \\
\text { II. The areas identified as stable were located at the same place where the superimposition reference area was. } \\
\text { III. Only average measures were used to assess all outcomes. There was no assessment of individual cases. } \\
\text { IV. Reproducibility outcomes were tested assessing the whole mandibular surface. } \\
\text { V. The performance of the chin+symphysis area was shown only for } 1 \text { subject. }\end{array}$ \\
\hline $\begin{array}{l}\text { Ruellas et al., } \\
\text { Am J Orthod Dentofacial Orthop } \\
(2016 a)\end{array}$ & $\begin{array}{l}\text { No clear evidence is provided that the } 2 \text { regions of } \\
\text { maxillary registration show similar results and adequate } \\
\text { intraobserver and interobserver reproducibility values for } \\
\text { growing patients. }\end{array}$ & $\begin{array}{l}\text { I. The changes measured were originally small, except from landmarks } 2 \text { and } 6 \text { where the error was greater. } \\
\text { II. In individual cases the amount of differences was not small compared to the original changes. } \\
\text { III. No detailed information is provided (e.g. Bland Altman plot for every variable and results for any landmarks and every } \\
\text { coordinates). Only means of different variables were assessed. } \\
\text { IV. No comparative statistics. }\end{array}$ \\
\hline $\begin{array}{l}\text { Ruellas et al., } \\
\text { PLoS One (2016b) }\end{array}$ & $\begin{array}{l}\text { The body of the mandible might show better agreement } \\
\text { with direct measurements from a point considered stable, } \\
\text { compared to the modified Björk superimposition. }\end{array}$ & $\begin{array}{l}\text { I. Results from one superimposition technique (Björk) are not reported. } \\
\text { II. The gold standard reference values were not reliable since one geometrical point that was speculated to be stable was used to } \\
\text { generate them. However, landmark point identification error is expected to be high in this case and this was not evaluated. } \\
\text { III. Two cases were not included in the analysis. } \\
\text { IV. Reported mean values were outside of the Limits of Agreements. }\end{array}$ \\
\hline $\begin{array}{l}\text { Weissheimer et al., } \\
\text { Int J Oral Maxillofac Surg (2015) }\end{array}$ & $\begin{array}{l}\text { The software seems to be user-friendly and might work } \\
\text { properly for voxel-based registration in the anterior cranail } \\
\text { base, both for growing and non-growing patients. }\end{array}$ & $\begin{array}{l}\text { I. No results quantification. } \\
\text { II. No method error. } \\
\text { III. No descriptive and comparative statistics. } \\
\text { IV. Only data from } 2 \text { patients shown. }\end{array}$ \\
\hline
\end{tabular}

